US Army Corps of Engineers ${ }_{\circledast}$

Engineer Research and

Development Center

Base Facilities Environmental Quality

\title{
A Regional Population Viability Approach for Threatened and Endangered Species Management on Army Installations
}

William R. Fields, Wade A. Wall, Brett A. DeGregorio,

March 2019

and Matthew G. Hohmann

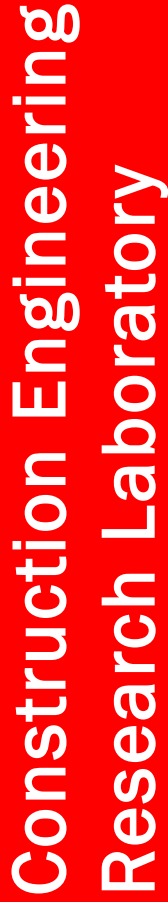

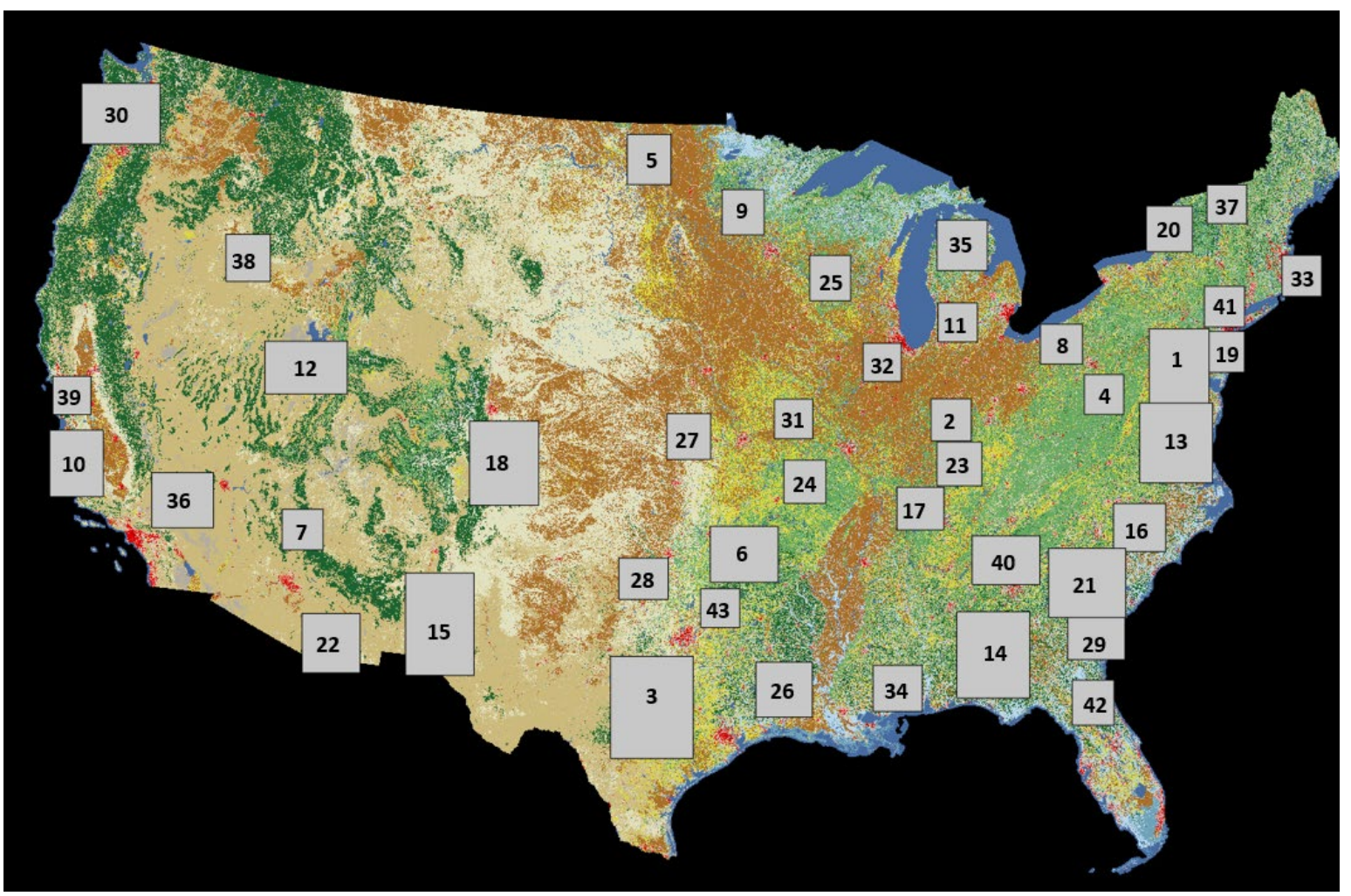


The U.S. Army Engineer Research and Development Center (ERDC) solves the nation's toughest engineering and environmental challenges. ERDC develops innovative solutions in civil and military engineering, geospatial sciences, water resources, and environmental sciences for the Army, the Department of Defense, civilian agencies, and our nation's public good. Find out more at www.erdc.usace.army.mil.

To search for other technical reports published by ERDC, visit the ERDC online library at http://acwc.sdp.sirsi.net/client/default. 


\section{A Regional Population Viability Approach for Threatened and Endangered Species Management on Army Installations}

William R. Fields, Wade A. Wall, Brett A. DeGregorio, and Matthew G. Hohmann

Construction Engineering Research Laboratory

U.S. Army Engineer Research and Development Center

2902 Newmark Drive

Champaign, IL 61822

Final report

Approved for public release; distribution is unlimited.

Prepared for Assistant Secretary of the Army for Acquisition, Logistics, and Technology 103 Army Pentagon

Washington, DC 20314-1000

Under Project P2 458334, "Regional Population Viability Approach for Threatened and Endangered Species Management on Army Installations"; Work Item BK8195, "Regional Partnering Prioritization for Threatened and Endangered Species Management." 


\section{Abstract}

Regional partnering for threatened and endangered species (TES) management can be an effective strategy, allowing the Department of Defense to achieve conservation goals while minimizing potential conflict with its training and testing missions. However, the potential benefits of regional partnering are determined by where TES habitat occurs within a landscape, how populations interact with one another demographically, and the proportion of TES habitat managed by various agencies and potential partners. To assess the opportunities for and potential value of regional TES conservation partnering, we evaluated the relative conservation values of habitat networks for 84 TES known to occur on or near 54 Army and Army National Guard installations. The highest relative network conservation values were estimated for mammals and birds at Fort Huachuca. High relative network conservation values are associated with large amounts of public land. On average, $52.3 \%$ of identified habitat networks occurred on public lands compared to $3.8 \%$ on private conservation lands. Assessment of habitat networks provides an efficient framework for guiding regional partnering efforts, and multispecies regional conservation partnerships will be critical in addressing the combined threats of encroachment and climate change. Prioritization of regional conservation partnerships will maximize the benefits of limited conservation funding.

DISCLAIMER: The contents of this report are not to be used for advertising, publication, or promotional purposes. Citation of trade names does not constitute an official endorsement or approval of the use of such commercial products. All product names and trademarks cited are the property of their respective owners. The findings of this report are not to be construed as an official Department of the Army position unless so designated by other authorized documents. 


\section{Contents}

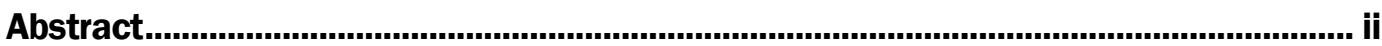

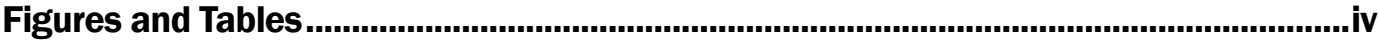

Preface

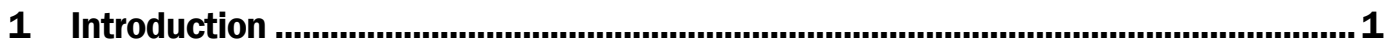

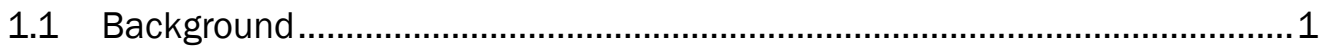

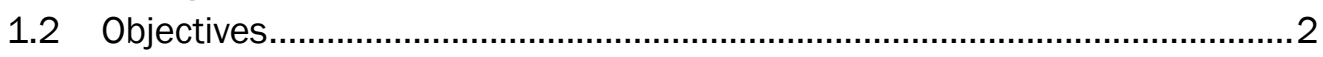

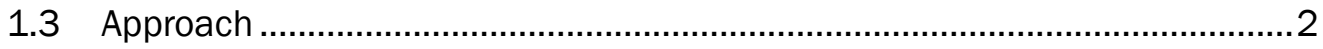

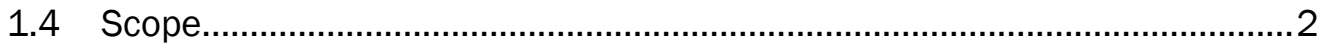

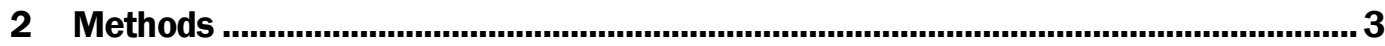

2.1 Species and dispersal information.............................................................

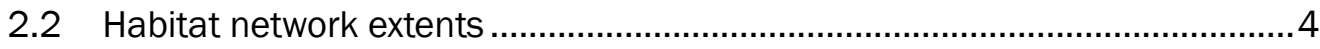

2.3 Habitat network delineation ...................................................................... 5

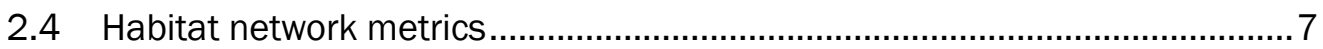

2.5 Habitat network assessment .................................................................. 7

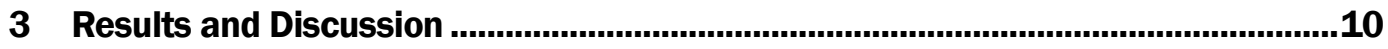

3.1 Listed species representation on installations........................................10

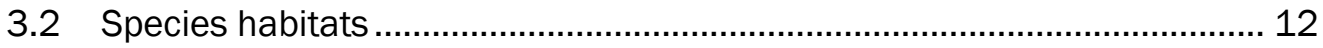

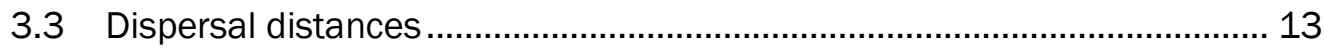

3.4 Habitat networks and relative conservation value .....................................14

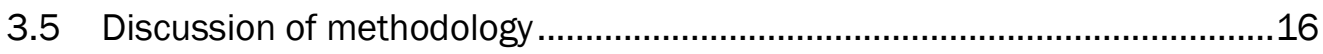

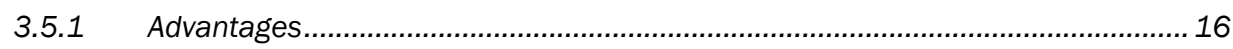

3.5.2 Challenges and limitations ........................................................................ 16

3.5.3 Potential extensions of the methodology ......................................................... 17

4 Conclusions and Recommendations..................................................................18

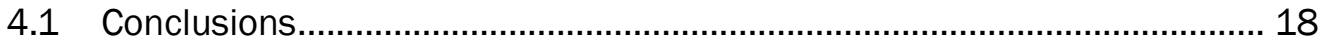

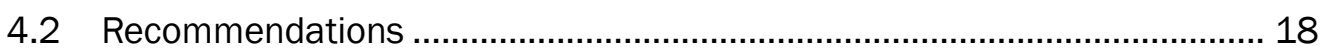

4.2.1 Incorporate approach and results into ACUB and REPI projectprioritization processes ............................................................................................... 18

4.2.2 Adopt approach and results as a screening-level tool for conservation assessment and management planning .......................................................................... 19

4.2.3 Adopt approach and results for developing novel mitigation approaches ............19

4.2.4 Expand analyses to include at-risk species...................................................... 20

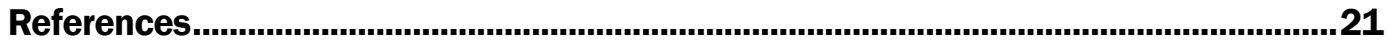

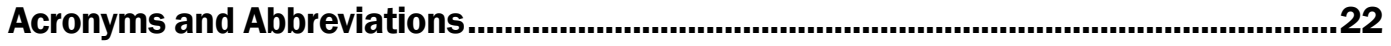

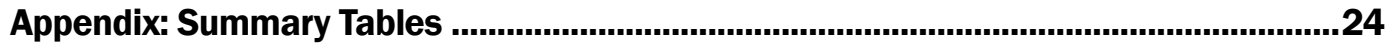

Report Documentation Page 


\section{Figures and Tables}

\section{Figures}

Figure 1. Habitat network extents for 54 Army and ARNG installations............................. 5

Figure 2. Mexican spotted owl habitat network around Fort Carson was

delineated in two stages...

Figure 3. Example of the distribution of GAP Status Codes for protected properties around Fort Carson.

Figure 4. Box plot* of the percentage of public lands with habitat networks having different relative network conservation value.

\section{Tables}

Table 1. GAP Status Codes and assigned conservation values........................................... 8

Table 2. Number of species on installations by occurrence type.

Table 3. Number of focal species utilizing different habitat types as characterized by the NLCD and NWI.

Table 4. Relative network conservation values for the top 12 networks. 


\section{Preface}

This study was conducted for the Office of the Assistant Secretary of the Army for Acquisition, Logistics, and Technology (ASA(ALT)) under Research, Development, Test, and Evaluation Program Element 896, "Base Facilities Environmental Quality; Project P2 458334, "Regional Population Viability Approach for Threatened and Endangered Species Management on Army Installations"; Work Item BK8195, "Regional Partnering Prioritization for Threatened and Endangered Species Management." The technical monitor for this work was Alan B. Anderson, CEERD-CZT, Technical Director for Sustainable Military Lands.

The work was performed by the Ecological Processes Branch of the Installations Division (CEERD-CNN), U.S. Army Engineer Research and Development Center, Construction Engineering Research Laboratory (ERDCCERL). At the time of publication, Dr. Chris Rewerts was Chief, CEERDCNN; and Michelle J. Hanson was Chief, CEERD-CN. The Deputy Director of ERDC-CERL was Dr. Kirankumar Topudurti and the Director was Dr. Lance D. Hansen.

The Commander of ERDC was COL Ivan D. Beckman and the Director was Dr. David W. Pittman. 
This page intentionally blank. 


\section{Introduction}

\subsection{Background}

Regional partnering for threatened and endangered species (TES) management can be an effective strategy, allowing the Department of Defense (DoD) to achieve conservation goals while minimizing potential conflict with its training and testing missions. Conservation planning that extends beyond installation boundaries can also present opportunities to leverage additional resources available to other partners. The success of regional partnering efforts depends on several factors, including the life history of species in question, the quality and quantity of lands surrounding an installation, the willingness of other agencies and land owners to engage in conservation actions, and the number of potentially benefiting species within a region. Although many diverse issues must be addressed to successfully implement conservation plans, a systematic assessment of landscapes around installations would be informative for initial identification of potential regional partnering opportunities.

Regional partnerships to achieve conservation goals are already used widely by DoD along with state and federal agencies. For example, the Gulf Coastal Plain Ecosystem Partnership in Florida includes 1 million acres* of public and private land that provide habitat for rare species while reducing the impact of encroaching development on Eglin Air Force Base, Pensacola Naval Air Station, and Naval Air Station Whiting Field. Within DoD, the Readiness and Environmental Protection Integration (REPI) Program, and the Army Compatible Use Buffer (ACUB) Program seek to protect habitats and buffer training activities from development without acquiring new land to manage. Over $\$ 275$ million in funds from the Army have been executed to protect over 200,000 acres of land in the ACUB Program, while the REPI Program has seen a combined expenditure of nearly $\$ 1.5$ billion from DoD and other partners to protect over 500,000 acres. The cost, scale, and importance of these programs makes a science-based approach essential in assessing the benefits of land conservation to TES.

\footnotetext{
* 1 acre $=0.40468564224$ hectare.
} 
Assessing the potential benefits of regional partnering for TES management requires determining where TES habitat occurs within a landscape, how populations in different areas of habitat interact with one another demographically, and the degree to which various management agencies and other potential partners own land containing TES habitat. Although the U.S. Geological Survey maintains the Protected Areas Database of the United States (PAD-US) to document where public lands and other protected areas are located around the country, evaluating TES habitat is more complex. Potential habitat not only must be mapped, but habitat patches also need to be viewed as networks that connect populations across the landscape through dispersal. This network, or metapopulation perspective, is necessary to provide information about the relative value of different habitat patches. Evaluating the relative importance of different areas of TES habitat and where it overlaps with different landowners is essential to providing a scientifically sound assessment of the benefits of regional partnering efforts.

\subsection{Objectives}

The objective of this work was to assess the opportunities for and potential value of regional TES conservation partnering involving 54 Army and Army National Guard installations around the country.

\subsection{Approach}

The objectives of this work were accomplished in three primary tasks:

1. Compiling information about TES life history, including dispersal distances and habitat use.

2. Aggregating spatial data for habitat conditions and land protection and management near all installations to be evaluated.

3. Examining the potential value of regional partnering around installations through the use of metapopulation metrics for TES.

\subsection{Scope}

This project evaluated the habitat networks within a $65 \mathrm{~km}$ buffer for 84 federally listed species known to occur on or near 54 continental U.S. (CONUS) Army and Army National Guard (ARNG) installations. 


\section{Methods}

To evaluate the potential effectiveness of regional partnering for improving the management of federally listed species, we updated a database of species occurrence on installations with Integrated Training Area Management (ITAM) programs and assessed the structure of regional habitat networks.

\subsection{Species and dispersal information}

In the past, large increases in the number of listed species on Army installations have not occurred, but an upsurge in listed species is now under way due to the proliferation of listing petitions and determinations. This change is a consequence of a settlement made between the U.S. Fish and Wildlife Service (USFWS) and the Center of Biodiversity (Endangered Species Act [ESA] Section 4 Deadline Litigation, Case Number 2165, U.S. District Court for the District of Columbia), which requires the USFWS to review 757 species petitioned for listing by an amended date of 2023. We obtained data for listed species occurrences on ITAM installations from the Office of the Assistant Chief of Staff for Installation Management (Steve Sekscienski, OACSIM-ISE, personal communication with author, December 2016). We then updated these data to include species listed through June 2018. Potential occurrence of recently listed species on 54 ITAM installations was assessed on the basis of official county-level distribution data contained in the USFWS Environmental Conservation Online System (ECOS), U.S. Geological Survey (USGS) Hydrological Map Unit (i.e., HUC-8) distribution data in NatureServe Explorer (NatureServe 2018), and installation geospatial data contained in PAD-US. After this update, the database contained occurrence information for 84 species, and 158 species-installation combinations (see Appendix).

After identifying focal species, we reviewed the published, peer-reviewed literature for information about the species dispersal capacity and habitats. For animals, some estimate of dispersal distances were generally available, but in the rare case when no information could be found, we used the separation distance for population/occurrence delineation described in NatureServe Explorer species reports (NatureServe 2018). For plants, species-specific estimates for seed-dispersal distances are typically unavailable, and dispersal models have only been developed for a few dis- 
persal modes (e.g., Tackenberg et al. 2003). Given the constraints on developing dispersal kernels for each of the many study species, we instead used a dispersal typology based on dispersal mode and plant traits to parameterize distance (Vitto and Engler 2007). This typology provides dispersal-distance estimates for seven types of dispersal as the upper limits of the distances (range $=0.1$ to $5000 \mathrm{~m}$ ) within which $50 \%$ and $99 \%$ of the seeds of a plant population are dispersed (Vitto and Engler 2007).

\subsection{Habitat network extents}

In order to delineate habitat networks, the spatial extent of a potential network must be defined. We first delineated a $65-\mathrm{km}$ buffer around each installation, and then used a bounding box that contained this buffer to limit the extent-of-habitat networks (Figure 1). The areas of habitat networks differed due to variation in the size of focal installations and due to merging of some networks among neighboring installations, but this approach generally resulted in large $\left(>19,600 \mathrm{~km}^{2}\right)$ spatial extents for habitat networks, which corresponded to raster data with $>22$ billion cells. A buffer of this size reduces the potential for edge effects in habitat networks while also preventing datasets from becoming so large that analyses become computationally intractable. Buffers larger than $65 \mathrm{~km}$ also would have caused the networks for many of the installations in the Southeast and mid-Atlantic regions to merge, resulting in unacceptably long data processing times. 
Figure 1. Habitat network extents for 54 Army and ARNG installations. Note that some installations have the same network identifier number due to the merging of their 65$\mathrm{km}$ buffers and assignment to a common bounding box. See number key below map.

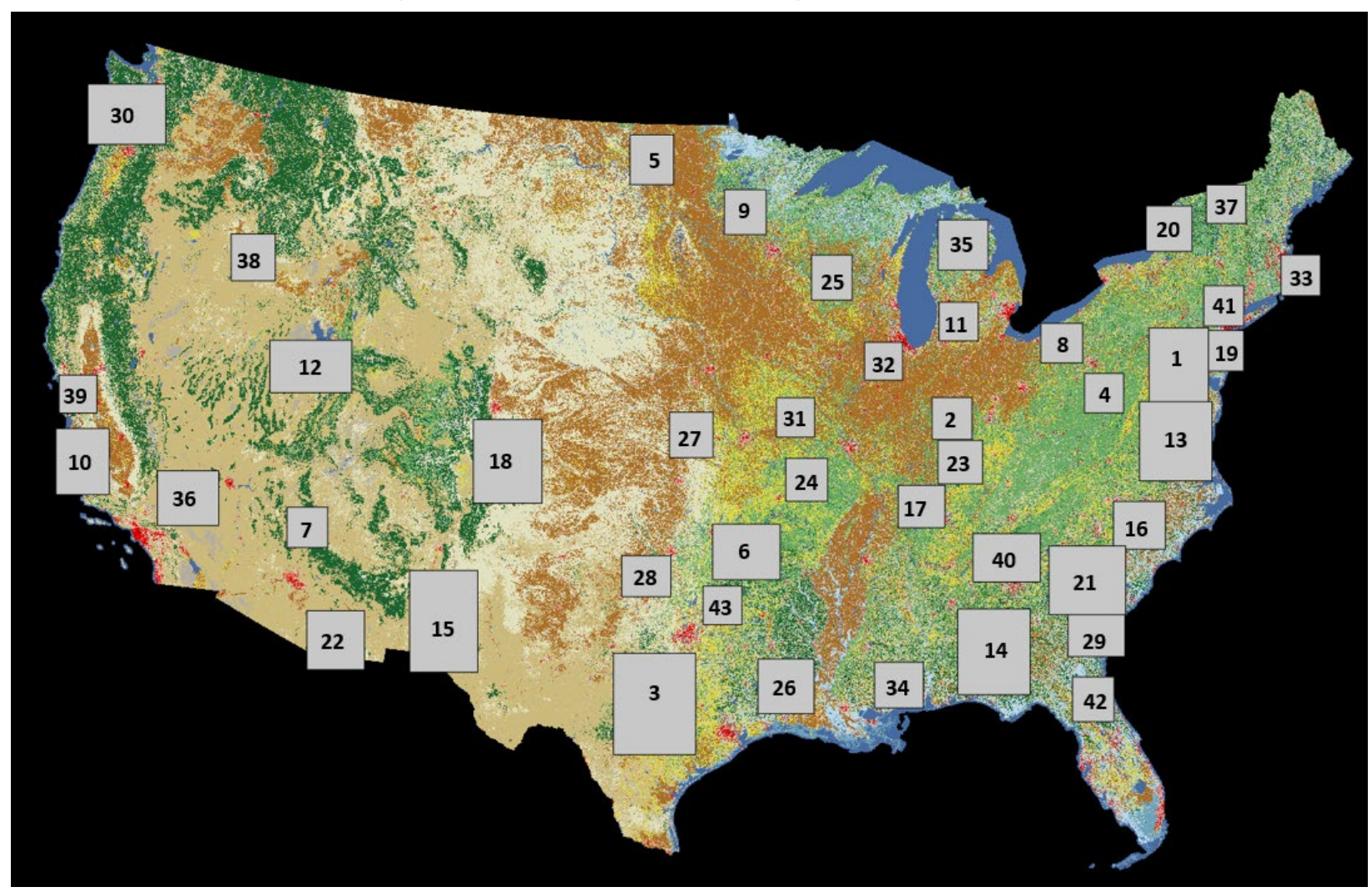

Key to habitat network extent numbers: Aberdeen Proving Ground (1), Camp Atterbury (2), Camp Blanding (42), Camp Bowie (3), Camp Dawson (4), Camp Grafton (5), Camp Gruber (6), Camp Maxey (43), Camp Navajo (7), Camp Ravenna ARNG JMTC (8), Camp Ripley (9), Camp San Luis Obispo (10), CTC Fort Custer Training Center (11), Dugway Proving Ground (12), Fort A.P. Hill (13), Fort Benning (14), Fort Bliss (15), Fort Bragg (16), Fort Campbell (17), Fort Carson (18), Fort Chaffee ARNG MTC (6), Fort Dix (19), Fort Drum (20), Fort Eustis (13), Fort Gordon (21), Fort Hood (3), Fort Huachuca (22), Fort Hunter Liggett (10), Fort Indiantown Gap (1), Fort Jackson (21), Fort Knox (23), Fort Lee (13), Fort Leonard Wood (24), Fort McCoy (25), Fort Pickett ARNG MTC (13), Fort Polk (26), Fort Riley (27), Fort Rucker (14), Fort Sill (28), Fort Stewart (29), Joint Base Lewis-McChord (30), Macon Training Site (31), Marseilles TC (32), MTA Camp Edwards (33), MTC Camp Shelby (34), MTC-H Camp Grayling (35), MTC-H Camp Roberts (10), National Training Center and Fort Irwin (36), NG TS Ethan Allen Range (37), Orchard TA (38), Parks RFTA (39), VTS Catoosa (40), West Point Military Reservation (41), and White Sands Missile Range (15).

\subsection{Habitat network delineation}

For each species at each installation, we delineated habitat networks by identifying species habitat associations from summary information in USFWS listing documents and selecting appropriate habitat types on focal installations and within their associated buffers (see Figure 2 example). We used the National Land Cover Database 2011 (NLCD; Homer et al. 2011) to delineate terrestrial habitat networks, and National Wetlands Inventory (NWI) data (Cowardin et al. 1979) to delineate aquatic habitat networks. 
Figure 2. Mexican spotted owl habitat network around Fort Carson was delineated in two stages. First, the NLCD (A) was queried to extract areas of potential habitat (evergreen forest). Second, LANDFIRE data (B) were used to exclude areas (C) where plant communities were significantly impacted by human activity (black). The remaining areas (green) were used to identify the Mexican spotted owl habitat network.

A

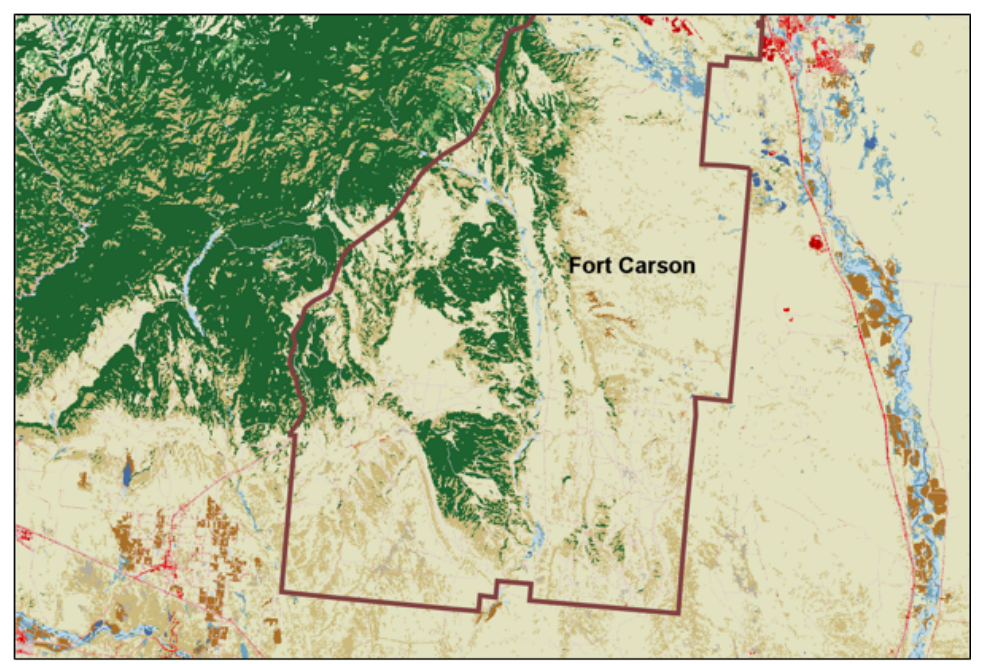

B

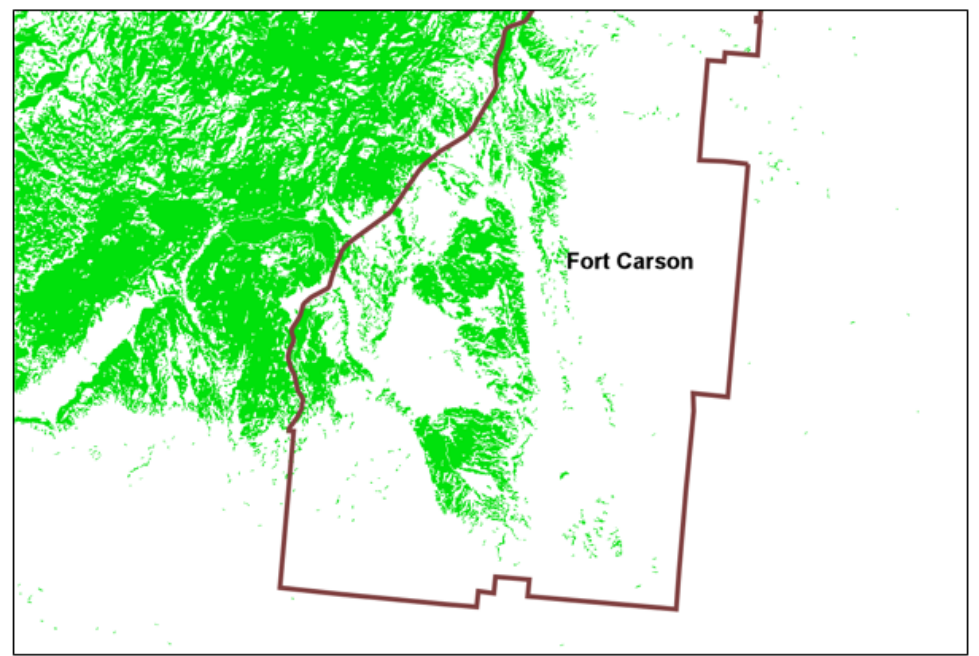

C

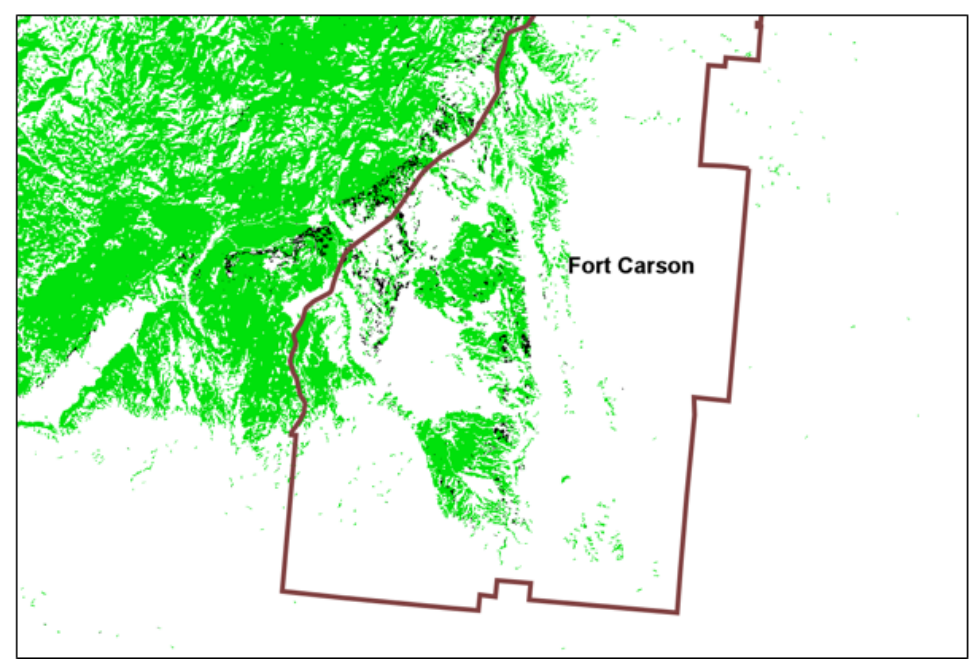


We selected the NLCD and NWI data for several pragmatic reasons. First, these data are consistently available across the U.S. Second, the prospect of generating distribution models for each individual species was not feasible given the limited occurrence data for many rare species and the scope of project duration. Third, the main objective of regional partnering for TES management is often to create more suitable habitat in areas where none currently exists, so it makes sense to consider the extent of evergreen forest for a species that requires some type of pine forest because evergreen forest is likely easier to restore than other types of land cover. Relying solely on maps of existing suitable habitat might produce virtually no information to guide regional partnering if TES habitat were extremely rare in the landscape surrounding an installation. For those habitat types delineated using NLCD classes, we also evaluated the quality of habitats using vegetation departure (VDEP) data contained in Landscape Fire and Resource Management Planning Tools (LANDFIRE) version 1.4 (Rollins 2006). Specifically we retained cells within the NLCD that are estimated to have departed from historical reference conditions by $<67 \%$ and excluded cells that were estimated to have departed $67 \%-100 \%$. This step effectively reduced the size and connectivity of habitat patches and networks.

\subsection{Habitat network metrics}

In order to evaluate the importance of potential habitat across the landscape, we assessed the relative value of individual habitat patches within networks (Hanski and Ovaskainen 2000). This approach weighs the importance of a habitat patch by considering its carrying capacity, which is assumed to be determined by patch size and proximity relative to the dispersal capacity of a species. For example, a large patch in close proximity to other patches would have high importance, while a small patch that was extremely isolated from other patches would have low importance. Details of this approach, which involve the eigenanalysis of a distance matrix for habitat patches weighted by the dispersal capacity of a species, can be found in Hanski and Ovaskainen (2000).

\subsection{Habitat network assessment}

After evaluating the potential contribution of habitat patches to metapopulations in landscapes surrounding installations, we then summarized information about habitat networks. First, we queried habitat networks with PAD-US data to determine the proportion of area within a network that 
was represented by public lands, private conservation lands, and other private lands. Networks with large areas of public land could present opportunities to partner with other agencies for TES management, potentially reducing TES encroachment on training lands while leveraging the resources of those agencies for mutual benefit.

Second, we calculated a relative conservation value for habitat networks by querying the networks with USGS Gap Analysis Program (GAP) status data from PAD-US (Table 1 and Figure 3). For each patch within a habitat network, we multiplied the conservation value by the patch value. For example, if a patch had a high metapopulation value and occurred in an area that had GAP status 1, its score would be $2 \times 4=8$. We then evaluated the relative conservation value of the entire habitat network by dividing the sum of observed patch values by the sum of the maximum potential patch values as shown below:

\section{Relative Network Conservation Value $=\sum$ patchi value $*$ patchi conservation value/ $/$ patchi value $* 4$}

This operation creates an index bounded between 0 and 1, with 1 representing a habitat network where all patches are permanently protected and managed to maintain biodiversity (i.e., GAP Status Code =1). Areas with the highest overall relative network conservation values are places where regional partnering may provide maximum benefit, while installations with the lowest overall relative network conservation values highlight areas where using regional partnering to reduce TES encroachment would probably be constrained (Table 1 ).

Table 1. GAP Status Codes and assigned conservation values.

\begin{tabular}{|c|l|l|}
\hline Domain Code & Description & Conservation Value \\
\hline 1 & $\begin{array}{l}\text { Managed for biodiversity, disturbance events } \\
\text { proceed or are mimicked }\end{array}$ & 4 points \\
\hline 2 & $\begin{array}{l}\text { Managed for biodiversity, disturbance events } \\
\text { suppressed }\end{array}$ & 3 points \\
\hline 3 & $\begin{array}{l}\text { Managed for multiple uses - subject to } \\
\text { extractive (mining/logging) or OHV use }\end{array}$ & 2 points \\
\hline 4 & No known mandate for biodiversity protection & 1 point \\
\hline
\end{tabular}

We also calculated the number of species present on installations and which habitat networks were used by more than one species. These calculations 
provide information both on which installations may face the most TES regulatory burden and which areas could benefit from efforts targeting umbrella species (Figure 3).

Figure 3. Example of the distribution of GAP Status Codes for protected properties around Fort Carson.

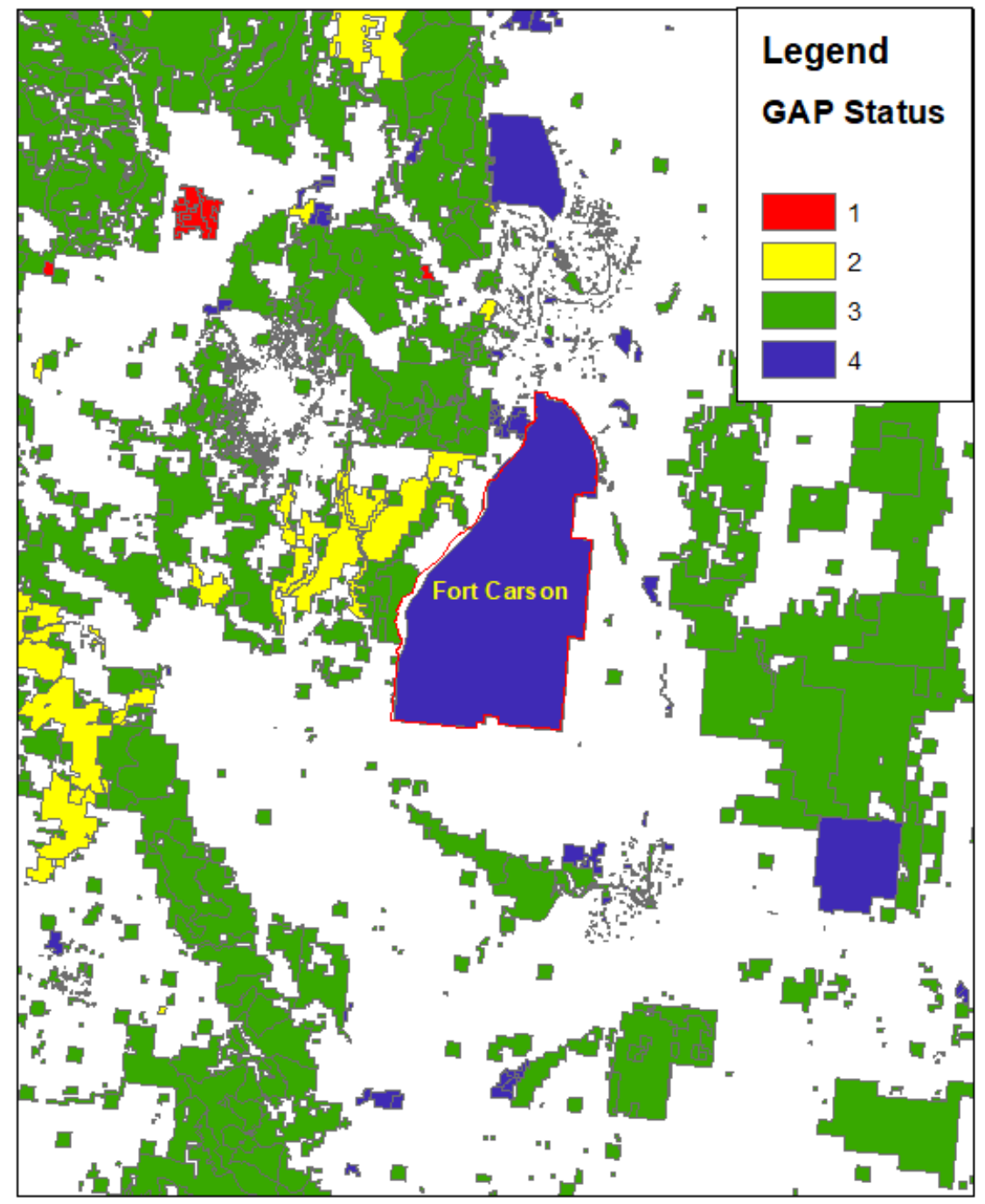

Data preparation and processing were performed using custom Python* scripts and GRASS GIS 7.4. (GRASS Development Team 2018). Statistical analyses were all performed using the R Statistical Package version 3.5 (R Core Team 2018). 


\section{Results and Discussion}

\subsection{Listed species representation on installations}

We identified 84 federally listed species that are known to occur on or near 54 CONUS Army and Army National Guard installations (see Tables A1 and A2 in the Appendix). The total number of species/installation combinations is only 156 , as there is limited redundancy in the representation of species across different installations (Table 2). In the majority of cases (110, or 75\%), species have been confirmed to occur onsite as opposed to occurring only in contiguous habitats (23) or probably occurring on installations (23). The latter group was almost exclusively assigned to the Northern Long-eared Bat, which has only been listed since 2015 and recently become the focus of installation surveys.

The number of listed species occurring on individual installations ranged from 1 to 14, averaging 2.90 per installation. Although Fort Huachuca had the largest number of species, the majority of those species (64\%) are only known from contiguous habitats as opposed to occurring onsite. Consequently, five other installations have the same or greater number of listed species onsite as Fort Huachuca.

Table 2. Number of species on installations by occurrence type.

\begin{tabular}{|l|c|c|c|c|}
\hline \multirow{2}{*}{\multicolumn{1}{|c|}{ Installation name (listed alphabetically) }} & \multicolumn{2}{c|}{$\begin{array}{c}\text { Number of species on installations } \\
\text { by occurrence type }\end{array}$} & \multirow{2}{*}{ Total } \\
\cline { 2 - 4 } & Onsite & Contiguous & Probable & \\
\hline ABERDEEN PROVING GROUND & & & 1 & 1 \\
\hline CAMP ATTERBURY & 4 & & & 4 \\
\hline CAMP BOWIE & 1 & & & 1 \\
\hline CAMP DAWSON & 2 & & 2 & 4 \\
\hline CAMP GRAFTON & & & 1 & 1 \\
\hline CAMP GRUBER & 1 & & 1 & 2 \\
\hline CAMP MAXEY & 1 & & & 1 \\
\hline CAMP NAVAJO & 1 & & & 1 \\
\hline CAMP RAVENNA ARNG JMTC & & & 1 & 1 \\
\hline CAMP RIPLEY & & 1 & 1 & 2 \\
\hline
\end{tabular}




\begin{tabular}{|c|c|c|c|c|}
\hline \multirow{2}{*}{ Installation name (listed alphabetically) } & \multicolumn{3}{|c|}{$\begin{array}{c}\text { Number of species on installations } \\
\text { by occurrence type }\end{array}$} & \multirow{2}{*}{ Tota } \\
\hline & Onsite & Contiguous & Probable & \\
\hline CAMP SAN LOUIS OBISPO & 1 & & & 1 \\
\hline CTC FORT CUSTER TRNG CENTER & & 1 & 1 & 2 \\
\hline DUGWAY PROVING GROUND & & 1 & & 1 \\
\hline FORT A P HILL & 3 & & & 3 \\
\hline FORT BENNING & 3 & & 1 & 4 \\
\hline FORT BLISS & 1 & & & 1 \\
\hline FORT BRAGG & 5 & & 1 & 6 \\
\hline FORT CAMPBELL & 2 & & 1 & 3 \\
\hline FORT CARSON & & 1 & & 1 \\
\hline FORT CHAFFEE ARNG MTC & 2 & & & 2 \\
\hline FORT DIX & & & 1 & 1 \\
\hline FORT DRUM & 1 & & 1 & 2 \\
\hline FORT EUSTIS & & & 1 & 1 \\
\hline FORT GORDON & 2 & & 1 & 3 \\
\hline FORT HOOD & 2 & & & 2 \\
\hline FORT HUACHUCA & 5 & 9 & & 14 \\
\hline FORT HUNTER LIGGETT & 5 & 2 & & 7 \\
\hline FORT INDIANTOWN GAP & & & 1 & 1 \\
\hline FORT JACKSON & 3 & & 1 & 4 \\
\hline FORT KNOX & 3 & & & 3 \\
\hline FORT LEE & & & 1 & 1 \\
\hline FORT LEONARD WOOD & 4 & & & 4 \\
\hline FORT MCCOY & 3 & 1 & & 4 \\
\hline FORT PICKETT ARNG MTC & 3 & & 1 & 4 \\
\hline FORT POLK & 2 & & 1 & 3 \\
\hline FORT RILEY & 2 & & 1 & 3 \\
\hline FORT RUCKER & 2 & & & 2 \\
\hline
\end{tabular}




\begin{tabular}{|c|c|c|c|c|}
\hline \multirow{2}{*}{ Installation name (listed alphabetically) } & \multicolumn{3}{|c|}{$\begin{array}{c}\text { Number of species on installations } \\
\text { by occurrence type }\end{array}$} & \multirow{2}{*}{ Tota } \\
\hline & Onsite & Contiguous & Probable & \\
\hline FORT SILL & 1 & & & 1 \\
\hline FORT STEWART & 7 & & & 7 \\
\hline JOINT BASE LEWIS-MCCHORD & 7 & 1 & & 8 \\
\hline MACON TRAINING SITE & 1 & & & 1 \\
\hline MARSEILLES TC & 1 & 2 & & 3 \\
\hline MTA CAMP EDWARDS & & & 1 & 1 \\
\hline MTA CAMP SHELBY & 3 & 2 & & 5 \\
\hline MTC CAMP BLANDING & 5 & & & 5 \\
\hline MTC-H CAMP GRAYLING & 4 & & & 4 \\
\hline MTC-H CAMP ROBERTS & 4 & & & 4 \\
\hline NATIONAL TRAINING CENTER AND FORT IRWIN & 2 & & & 2 \\
\hline NGO TS ETHAN ALLEN RANGE & & & 1 & 1 \\
\hline ORCHARD TA & 1 & & & 1 \\
\hline PARKS RFTA & 1 & 1 & & 2 \\
\hline VTS CATOOSA & 3 & & & 3 \\
\hline WEST POINT MILITARY RESERVATION & 2 & & & 2 \\
\hline WHITE SANDS MISSILE RANGE & 4 & 1 & & 5 \\
\hline Grand Total & 110 & 23 & 23 & 156 \\
\hline
\end{tabular}

\subsection{Species habitats}

Species inhabit diverse habitat types as classified by the NLCD and NWI (Table 3), but wetland habitats are most frequently utilized. Among strictly terrestrial habitats, evergreen forest was most commonly used by listed species. This is not surprising given that the ranges of many species are either wholly or partially restricted to the southeastern US where evergreen forest was historically the dominant land cover type. 
Table 3. Number of focal species utilizing different habitat types as characterized by the NLCD and NWI.

\begin{tabular}{|c|c|c|}
\hline $\begin{array}{l}\text { Data } \\
\text { Source }\end{array}$ & Habitat Type & $\begin{array}{l}\text { Number of Species } \\
\text { Utilizing Habitat Type* }\end{array}$ \\
\hline \multirow{9}{*}{ NLCD } & Barren Land (Rock/Clay/Sand) & 4 \\
\hline & Deciduous Forest & 9 \\
\hline & Emergent Herbaceous Wetlands & 13 \\
\hline & Evergreen Forest & 17 \\
\hline & Grassland/Herbaceous & 10 \\
\hline & Mixed Forest & 16 \\
\hline & Open Water & 15 \\
\hline & Shrub/Scrub & 7 \\
\hline & Woody Wetlands & 9 \\
\hline \multirow{4}{*}{ NWI } & Estuarine & 4 \\
\hline & Lacustrine & 3 \\
\hline & Palustrine & 20 \\
\hline & Riparian & 12 \\
\hline
\end{tabular}

\subsection{Dispersal distances}

The dispersal capacity of species differed markedly among species and taxonomic groups, exhibiting a range of 0.0001 to $1500 \mathrm{~km}$ and a median of $1.6 \mathrm{~km}$ (see Table A1 in the Appendix). Among taxonomic groups, plants have the shortest dispersal distances, but multiple rodent, amphibian, and reptile species also exhibit very limited dispersal capacities. In contrast anadromous fish, including several salmonid and sturgeon species, have the greatest dispersal capacities when movement is not limited by physical barriers. 


\subsection{Habitat networks and relative conservation value}

Across species and installations the relative conservation values of habitat networks ranged from 0.2 to 0.6 (see Table A3 in the Appendix). Except for the Huachuca water umbel, the 12 highest relative network conservation values were estimated for mammals and birds (Table 4). Seven of the twelve highest relative network conservation values were estimated for species at Fort Huachuca (Table 4). In contrast the lowest values (0.2), albeit limited to three species, were estimated for two plant (American Chaffseed and Michaux's Sumac on Fort Bragg, NC) and one invertebrate species (Oregon Silverspot on Camp Rilea, OR).

Table 4. Relative network conservation values for the top 12 networks.

\begin{tabular}{|l|l|l|}
\hline Installation & Species & $\begin{array}{l}\text { Relative Network } \\
\text { Conservation Value }\end{array}$ \\
\hline Fort Huachuca & Lesser Long-Nosed Bat & 0.6 \\
\hline Fort Huachuca & Mexican Spotted Owl & 0.6 \\
\hline Fort Huachuca & Jaguar & 0.6 \\
\hline Fort Huachuca & $\begin{array}{l}\text { Northern Mexican } \\
\text { Gartersnake }\end{array}$ & 0.6 \\
\hline Fort Huachuca & Ocelot & 0.5 \\
\hline $\begin{array}{l}\text { White Sands Missile } \\
\text { Range }\end{array}$ & $\begin{array}{l}\text { Western Yellow-billed } \\
\text { Cuckoo }\end{array}$ & 0.5 \\
\hline Fort Huachuca & Huachuca Water-Umbel & 0.5 \\
\hline MTC-H Camp Grayling & Kirtland's Warbler & 0.5 \\
\hline Camp Navajo & Mexican Spotted Owl & 0.5 \\
\hline $\begin{array}{l}\text { Joint Base Lewis- } \\
\text { McChord }\end{array}$ & Northern Spotted Owl & 0.5 \\
\hline MTC Camp Blanding & Wood Stork & 0.5 \\
\hline Fort Huachuca & $\begin{array}{l}\text { Southwestern Willow } \\
\text { Flycatcher }\end{array}$ & 0.5 \\
\hline
\end{tabular}

Patterns of land ownership for habitat networks vary considerably (see Table A4 in the Appendix), but installations with higher percentages of public lands within their buffers tend to have higher relative network conservation values (Figure 4). For example, $99.1 \%$ of the habitat network 
for the lesser long-nosed bat around Fort Huachuca is represented by public lands, while $\mathrm{o} \%$ of the habitat network for Topeka shiner around Fort Riley is public land. On average $52.3 \%$ of habitat networks were contained in public lands, but only $3.8 \%$ of habitat networks were contained in private conservation lands. Many habitat networks with the highest percentage of public land were located in the western U.S., with some of the highest being for forested habitat networks in arid environments (e.g., see Table A3 in Appendix for networks associated with Fort Huachuca).

Figure 4. Box plot* of the percentage of public lands with habitat networks having different relative network conservation value.

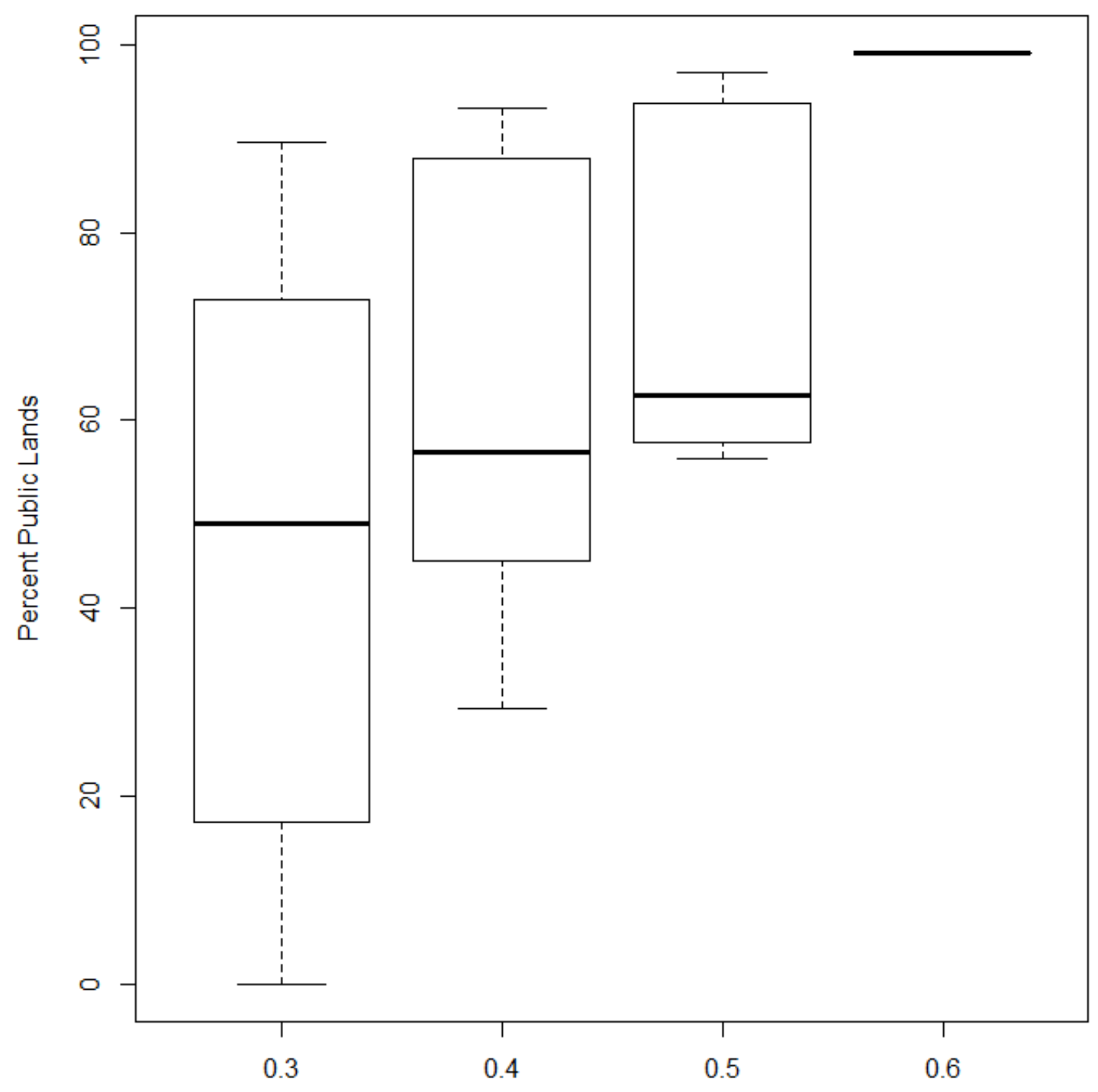

Relative Network Conservation Value

*Boxes represent $50 \%$ of the data, the bold line in boxes is the median, and whisker includes $95 \%$ of the data. 


\subsection{Discussion of methodology}

\subsubsection{Advantages}

This approach for evaluating the conservation status of habitat networks has several advantages. First, the approach outlined here could easily leverage monitoring data where it is available. Many installations have ongoing monitoring programs for TES, and their data could be used to generate better maps of potential habitat and to provide additional insights into the dispersal capacity of individual species. Second, the evaluation of habitat networks for species is highly efficient thanks to a package that allows the $\mathrm{R}$ programming language to call a Fortran library. This process is limited by the memory in a computer, which places constraints on how big objects in the R programming language can be. Third, this approach can support decision making through the production of maps that can be integrated with other spatial data within a geographic information system. This approach provides detailed information about both the location of areas of conservation value and TES encroachment.

\subsubsection{Challenges and limitations}

This analysis relies largely on expert opinion to generate habitat networks. NLCD and LANDFIRE data may not fully capture the relevant variation about the quality of habitat for all species, but we lacked data to empirically model species distributions around all of the installations that were included in this project. We also had to rely on expert opinion in assessing the dispersal capacity of species in some cases where data were lacking for a species.

The assessment of habitat networks utilized GAP status scores from a national dataset, which was the best source of information for this project. However, GAP status may not capture all of the relevant conservation initiatives that are under way in the field. These data were appropriate for comparing places across the country, but additional local information and expert knowledge should be sought if projects were to be initiated at specific installations.

Finally, this analysis relied on a snapshot of habitat conditions at one point in time, but habitat networks are likely to be dynamic. Developed areas are likely to expand in many places, and the vegetative communities across these landscapes could be affected by shifting weather patterns, 
successional processes, and large-scale disturbances like wildfires or disease. The work required for the scope of this analysis did not allow us to consider such factors. However, if a subset of installations were selected for further analyses, it could be useful to examine models of future land cover conditions or conservation risk factors.

\subsubsection{Potential extensions of the methodology}

This approach could be extended by conducting a formal prioritization analysis of the habitat networks. For example, if information about costs or total land-area constraints are relevant to the decision making process, reserve-selection software such as MARXAN could be included in the procedure (Ball and Possingham 2000, Watts et al. 2009). Other prioritization methods such as the edge-deletion algorithm used in Zonation can identify contiguous areas of high conservation value with linkages that could facilitate dispersal across the landscape (Moilanen et al. 2005). Such approaches make it possible to incorporate multiple species into analyses, which could be desirable for some installations. Perhaps more significantly, these approaches could also be modified to assess how constraints in the form of competing land uses might affect prioritization of areas to reduce TES encroachment. Information about training activities on installations at the level of training areas also could be incorporated into analyses to better understand where TES encroachment could cause problems as well as opportunities for mitigation activities. 


\section{Conclusions and Recommendations}

\subsection{Conclusions}

Conservation planning that seeks to engage regional partners has the potential to provide greater flexibility in how the Army mitigates adverse impacts of training and testing missions on listed species. Assessment of habitat networks provides an efficient framework for guiding regional partnering efforts. We have shown how the concept of metapopulation capacity combined with information on vegetation departure and land protection status can be used to characterize the quality of habitat networks for a diverse suite of species of conservation concern to the Army. More specifically, the approach can also be used to inform multiple aspects of species and habitat conservation, including local and landscape mitigation as well as species recovery.

Multispecies regional conservation partnerships will continue to be a critical component of a broader strategy used by Army and DoD to address the combined threats of encroachment and climate change. It is important that these regional conservation partnership efforts are prioritized to provide maximal benefits given the severe limitations on conservation funding.

\subsection{Recommendations}

\subsubsection{Incorporate approach and results into ACUB and REPI project- prioritization processes}

The Army ACUB and REPI programs, which are designed to limit encroachment and protect TES and their habitats, have been implemented widely across the country with great success. Among other considerations, funding decisions in these programs are based on (1) the encroachment threat to the military mission, (2) the potential to prevent or mitigate impacts, and (3) the potential to prevent encroachment on a landscape level. Although conservation of TES and their habitats at landscape scales can improve regional viability, there is no guarantee that metapopulation processes that are necessary to promote colonization of unoccupied habitats or augment existing populations will be enhanced. Those goals require explicit consideration of species dispersal capacities and habitat connectivity. We recommend that our results and approach be considered for inclusion within the decision-making processes of the ACUB and REPI 
programs in order to evaluate whether the metapopulations of focal conservation species are optimally benefited.

\subsubsection{Adopt approach and results as a screening-level tool for conservation assessment and management planning}

While ACUB and REPI programs are effective at expanding the protected land base for species conservation, the conservation benefits of existing protected properties can often be improved. We envision the information and approach generated by this effort can be used as a screening-level tool to enhance conservation assessment and management planning in at least

two ways. First, installations with high potential to benefit from partnering should formalize conservation partnerships with existing managers of habitats that contribute to species metapopulation capacities. Second, the approach can be used to target habitat improvement and restoration efforts for maximal conservation benefit by evaluating improvements in metapopulation capacity. For example, comparing the metapopulation capacity for all areas of relevant habitat type(s) versus the reduced area that accounts for vegetation departure from historical conditions would identify the potential benefits of additional habitat-management efforts. These screening-level applications can be implemented at both installation and regional scales.

\subsubsection{Adopt approach and results for developing novel mitigation approaches}

Adverse impacts to listed species resulting from military land use and management are anticipated and commonly offset using various mitigation approaches. Ideally, mitigation is applied in a strategic manner that ensures an effective linkage with conservation strategies at appropriate landscape scales. For example, when TES populations are at carrying capacity on installations, surplus individuals disperse away from the installation and colonize new habitat patches or augment existing populations elsewhere. This process is the foundation of metapopulation dynamics and directly increases overall regional viability for a species. Unfortunately, because installations are typically viewed independently, these surplus individuals generated on the installation do not generate credit for the installation that produced them. If the management actions on the installation are enhancing regional metapopulation viability for the managed species, then this contribution should be quantified and taken into account during ESA section 7 consultation with USFWS when training restrictions 
are considered and imposed. Estimates of metapopulation capacity, supplemented with appropriate demographic and dispersal data should be used by installations and the USFWS to provide greater flexibility in how the Army mitigates adverse impacts of training and testing missions on species of interest.

\subsubsection{Expand analyses to include at-risk species}

Although our analyses were limited to federally listed species, the approach can readily be extended to DoD species at risk (SAR). These are species that are not currently listed as threatened or endangered under the ESA, but are (1) proposed or candidates for listing, or (2) categorized as critically imperiled or imperiled (G1 or G2) throughout their range by NatureServe, or are birds categorized as vulnerable (G3), and (3) have at least one population on or near (within a $2 \mathrm{~km}$ buffer) a DoD installation (NatureServe 2015). DoD has embraced proactive conservation of SAR as an effective strategy for range and readiness sustainment. Numerous species and installations (e.g., Camp Shelby burrowing crayfish, Fallicambarus gordoni) have benefited from proactive conservation actions and plans (e.g., candidate conservation agreements) to the extent that listing under the ESA has not been warranted. 


\section{References}

Ball, I.R., and H.P. Possingham. 2000. MARXAN (V1. 8.2). Marine Reserve Design Using Spatially Explicit Annealing (a manual).

Cowardin, L. M., Carter, V., Golet, F. C., and LaRoe, E. T. 1979. Classification of wetlands and deepwater habitats of the United States. Washington, DC: U.S. Department of the Interior, Fish and Wildlife Service.

GRASS Development Team. 2018. Geographic Resources Analysis Support System (GRASS) Software, Version 7.4. Open Source Geospatial Foundation. Accessed 12 February 2018, http://grass.osgeo.org.

Hanski, I., and O. Ovaskainen. 2000. The metapopulation capacity of a fragmented landscape. Nature 404:755-758.

Homer, C.G., Dewitz, J. A., Yang, L., Danielson, P., Xian, G., Coulston, J., Herold, N.D., Wickham, J. D., and Megown, K. 2015. Completion of the 2011 National Land Cover Database for the conterminous United States-Representing a decade of land cover change information. Photogrammetric Engineering and Remote Sensing 81: $345-354$.

Moilanen A., Franco, A.M.A., Early, R.I., Fox, R., Wintle, B.A., and Thomas, C.D. 2005. Prioritizing multiple-use landscapes for conservation: methods for large multispecies planning problems. Proceeding of the Royal Society of London Series B 272:1885-1891.

NatureServe. 2015. Species at Risk on Department of Defense Lands: 2014 Updated Analysis, Report and Maps. Final Report, Project 14-772. Department of Defense Legacy Program.

NatureServe. 2018. NatureServe Explorer: An online encyclopedia of life [web application]. Version 7.1. Arlington, VA: NatureServe. Available http://explorer.natureserve.org

R Development Core Team. 2018. R: a Language and environment for statistical computing. Vienna, Austria.

Rollins, M. G. 2006. LANDFIRE: a nationally consistent vegetation, wildland fire, and fuel assessment. International Journal of Wildland Fire 18:235-249.

Tackenberg, O. 2003. Modeling long-distance dispersal of plant diaspores by wind. Ecological Monographs 73:173-189.

Vitto, P. and R. Engler. 2007. Seed dispersal distances: a typology based on dispersal modes and plants traits. Botanica Helvetica 117:109-124.

Watts, Matthew E., Ian R. Ball, Romola S. Stewart, Carissa J. Klein, Kerrie Wilson, Charles Steinback, Reinaldo Lourival, Lindsay Kircher, and Hugh P. Possingham. 2009. Marxan with Zones: software for optimal conservation based land-and seause zoning. Environmental Modelling and Software 24(12): 1513-1521. 


\section{Acronyms and Abbreviations}

\begin{tabular}{|c|c|}
\hline Term & Definition \\
\hline ACUB & Army Compatible Use Buffer \\
\hline ARNG & Army National Guard \\
\hline BLM & Bureau of Land Management \\
\hline CEERD & U.S. Army Corps of Engineers, Engineer Research and Development Center \\
\hline CERL & Construction Engineering Research Laboratory \\
\hline CONUS & Continental US \\
\hline СTC & Combined Training Center \\
\hline DoD & U.S. Department of Defense \\
\hline DOI & U.S. Department of Interior \\
\hline ECOS & Environmental Conservation Online System \\
\hline ERDC & U.S. Army Engineer Research and Development Center \\
\hline ERDC-CERL & $\begin{array}{l}\text { Engineer Research and Development Center, Construction Engineering } \\
\text { Research Laboratory }\end{array}$ \\
\hline ESA & Endangered Species Act \\
\hline GAP & USGS Gap Analysis Program \\
\hline HUC & Hydrologic Unit Codes \\
\hline INRMP & Integrated Natural Resources Management Plan \\
\hline ITAM & Integrated Training Area Management \\
\hline JMTC & Joint Military Training Center \\
\hline LANDFIRE & Landscape Fire and Resource Management Planning Tools \\
\hline MTA & Military Training Area \\
\hline MTC & Military Training Center \\
\hline NGO & Nongovernmental Organization \\
\hline NLCD & National Land Cover Data \\
\hline NWI & National Wetland Inventory \\
\hline OACSIM-ISE & $\begin{array}{l}\text { Office of the Assistant Chief of Staff for Installation Management, Army } \\
\text { Environmental Division }\end{array}$ \\
\hline
\end{tabular}




\begin{tabular}{|l|l|}
\hline Term & Definition \\
\hline OHV & Off Highway Vehicle \\
\hline PAD & Protected Areas Database \\
\hline REPI & Readiness and Environmental Protection Integration \\
\hline SAR & Species at Risk \\
\hline TA & Training Area \\
\hline TES & Threatened and Endangered Species \\
\hline U.S. & United States \\
\hline USFS & U.S. Forest Service \\
\hline USFWS & U.S. Fish and Wildife Service \\
\hline USGS & U.S. Geological Survey \\
\hline VDEP & Vegetation Departure \\
\hline VTS & Volunteer Training Site \\
\hline
\end{tabular}




\section{Appendix: Summary Tables}

Table A1. Eighty-four federally listed species occurring on 55 cONUS Army and Army National Guard Installations, and associated distances and primary habitats.

\begin{tabular}{|c|c|c|c|c|c|c|}
\hline Scientific Name & Common Name & $\begin{array}{l}\text { Number of } \\
\text { Installations }\end{array}$ & Listing Status & $\begin{array}{l}\text { Distance } \\
(\mathrm{km})\end{array}$ & NLCD Habitat & NWI Habitat \\
\hline $\begin{array}{l}\text { Acipenser } \\
\text { brevirostrum }\end{array}$ & Sturgeon, Shortnose & 1 & ENDANGERED & 1000 & Open Water & $E, R$ \\
\hline $\begin{array}{l}\text { Acipenser oxyrinchus } \\
\text { oxyrinchus }\end{array}$ & $\begin{array}{l}\text { Sturgeon, Atlantic (South Atlantic } \\
\text { DPS) }\end{array}$ & 1 & ENDANGERED & 1500 & Open Water & $E, R$ \\
\hline $\begin{array}{l}\text { Ambystoma } \\
\text { californiense }\end{array}$ & $\begin{array}{l}\text { Salamander, California Tiger } \\
\text { (Central CA DPS, not including } \\
\text { Santa Barbara and Sonoma DPS) }\end{array}$ & 2 & THREATENED & 0.25 & Grassland/Herbaceous & $\mathrm{P}$ \\
\hline $\begin{array}{l}\text { Ambystoma } \\
\text { cingulatum }\end{array}$ & Salamander, Frosted Flatwoods & 1 & THREATENED & 0.45 & Woody Wetlands & PFO4 \\
\hline $\begin{array}{l}\text { Ambystoma tigrinum } \\
\text { stebbinsi }\end{array}$ & Salamander, Sonora Tiger & 1 & ENDANGERED & 0.25 & Emergent Herbaceous Wetlands & PUBH \\
\hline Anaxyrus californicus & Toad, Arroyo & 1 & ENDANGERED & 0.5 & Woody Wetlands & R4SB3 \\
\hline $\begin{array}{l}\text { Aphelocoma } \\
\text { coerulescens }\end{array}$ & Scrub-jay, Florida & 1 & THREATENED & 1.5 & Shrub/Scrub & $\mathrm{n} / \mathrm{a}$ \\
\hline $\begin{array}{l}\text { Astragalus } \\
\text { jaegerianus }\end{array}$ & Milk-vetch, Lane Mountain & 1 & ENDANGERED & 0.04 & Shrub/Scrub & $\mathrm{n} / \mathrm{a}$ \\
\hline Bombus affinis & Bumble Bee, Rusty Patched & 2 & ENDANGERED & 1 & Grassland/Herbaceous & $\mathrm{n} / \mathrm{a}$ \\
\hline $\begin{array}{l}\text { Brachylagus } \\
\text { idahoensis }\end{array}$ & $\begin{array}{l}\text { Rabbit, Pygmy (Columbia Basin } \\
\text { DPS) }\end{array}$ & 1 & ENDANGERED & 2 & Shrub/Scrub & $\mathrm{n} / \mathrm{a}$ \\
\hline Branchinecta lynchi & Fairy shrimp, Vernal Pool & 2 & THREATENED & 1 & Emergent Herbaceous Wetlands & PEM2C \\
\hline Charadrius melodus & $\begin{array}{l}\text { Plover, Piping (All areas except } \\
\text { Great Lakes watershed of IL, IN, MI, } \\
\text { MN, NY, OH, PA, and WI) }\end{array}$ & 1 & THREATENED & 1 & Barren Land (Rock/Clay/Sand) & $\begin{array}{l}\text { R2US1, R2US2, } \\
\text { R3US1, R3US2, } \\
\text { L2US2 }\end{array}$ \\
\hline $\begin{array}{l}\text { Chlorogalum } \\
\text { purpureum }\end{array}$ & Amole, Purple & 2 & THREATENED & 0.001 & Mixed Forest & $\mathrm{n} / \mathrm{a}$ \\
\hline Coccyzus americanus & $\begin{array}{l}\text { Cuckoo, Yellow-billed Western } \\
\text { Population Segment }\end{array}$ & 1 & THREATENED & 500 & Deciduous Forest & $\mathrm{n} / \mathrm{a}$ \\
\hline $\begin{array}{l}\text { Coryphantha sneedii } \\
\text { var. sneedii }\end{array}$ & Cactus, Sneed Pincushion & 1 & ENDANGERED & 0.04 & Barren Land (Rock/Clay/Sand) & $\mathrm{n} / \mathrm{a}$ \\
\hline $\begin{array}{l}\text { Cumberlandia } \\
\text { monodonta }\end{array}$ & Spectaclecase & 1 & ENDANGERED & 2 & Open Water & R2UB1 \\
\hline $\begin{array}{l}\text { Cyprinodon } \\
\text { macularius }\end{array}$ & Pupfish, Desert & 1 & ENDANGERED & 10 & Emergent Herbaceous Wetlands & $P$ \\
\hline Dendroica chrysoparia & Warbler, Golden-cheeked & 1 & ENDANGERED & 0.2 & Deciduous Forest & $\mathrm{n} / \mathrm{a}$ \\
\hline $\begin{array}{l}\text { Drymarchon corais } \\
\text { couperi }\end{array}$ & Snake, Eastern Indigo & 2 & THREATENED & 4.8 & Evergreen Forest & $\mathrm{n} / \mathrm{a}$ \\
\hline
\end{tabular}




\begin{tabular}{|c|c|c|c|c|c|c|}
\hline Scientific Name & Common Name & $\begin{array}{l}\text { Number of } \\
\text { Installations }\end{array}$ & Listing Status & $\begin{array}{l}\text { Distance } \\
(\mathrm{km})\end{array}$ & NLCD Habitat & NWI Habitat \\
\hline Echinacea laevigata & Coneflower, Smooth & 2 & ENDANGERED & 0.001 & Grassland/Herbaceous & $n / a$ \\
\hline Eliptio lanceolata & Lance, Yellow & 1 & THREATENED & 2 & Open Water & R2UB2 \\
\hline $\begin{array}{l}\text { Empidonax traillii } \\
\text { extimus }\end{array}$ & Flycatcher, Southwestern Willow & 2 & ENDANGERED & 16 & Woody Wetlands & PSS, PFO \\
\hline Epioblasma triquetra & Mussel, Snuffbox & 1 & ENDANGERED & 2 & Open Water & L2US2, R2UB1 \\
\hline $\begin{array}{l}\text { Eremophila alpestris } \\
\text { strigata }\end{array}$ & Horned Lark, Streaked & 1 & THREATENED & 10 & Grassland/Herbaceous & $n / a$ \\
\hline $\begin{array}{l}\text { Euphydryas editha } \\
\text { taylori }\end{array}$ & Butterfly, Taylor's Checkerspot & 1 & ENDANGERED & 0.1 & Grassland/Herbaceous & $n / a$ \\
\hline Geocarpon minimum & Geocarpon & 1 & THREATENED & 0.0001 & Barren Land (Rock/Clay/Sand) & $n / a$ \\
\hline Gila intermedia & Chub, Gila & 1 & ENDANGERED & 15 & Emergent Herbaceous Wetlands & R3, P \\
\hline Gopherus agassizii & $\begin{array}{l}\text { Tortoise, Desert (except AZ south } \\
\text { and east of Colorado River, and } \\
\text { Mexico) }\end{array}$ & 1 & THREATENED & 5 & Shrub/scrub & $n / a$ \\
\hline Gopherus polyphemus & $\begin{array}{l}\text { Tortoise, Gopher (Wherever found } \\
\text { west of Mobile and Tombigbee } \\
\text { Rivers in AL, MS, and LA) }\end{array}$ & 1 & THREATENED & 0.5 & Evergreen Forest & $n / a$ \\
\hline $\begin{array}{l}\text { Gymnogyps } \\
\text { californianus }\end{array}$ & $\begin{array}{l}\text { Condor, California (Entire, except } \\
\text { where listed as experimental } \\
\text { populations) }\end{array}$ & 1 & ENDANGERED & 70 & Grassland/Herbaceous & $n / a$ \\
\hline Hedeoma todsenii & Pennyroyal, Todsen's & 1 & ENDANGERED & 0.0001 & Evergreen Forest & $n / a$ \\
\hline Helonias bullata & Pink, Swamp & 1 & THREATENED & 0.002 & Woody Wetlands & PFO \\
\hline Howellia aquatilis & Howellia, Water & 1 & THREATENED & 0.0001 & Emergent Herbaceous Wetlands & PAB3C \\
\hline Isoetes louisianensis & Quillwort, Louisiana & 1 & ENDANGERED & 0.0001 & Woody Wetlands & R2AB \\
\hline Isotria medeoloides & Pogonia, Small Whorled & 1 & THREATENED & 0.002 & Deciduous Forest & $n / a$ \\
\hline $\begin{array}{l}\text { Leopardus (=Felis) } \\
\text { pardalis }\end{array}$ & Ocelot & 1 & ENDANGERED & 8 & Deciduous Forest & $n / a$ \\
\hline Lepidium papilliferum & Peppergrass, Slickspot & 1 & THREATENED & 0.0001 & Shrub/Scrub & $n / a$ \\
\hline $\begin{array}{l}\text { Leptonycteris } \\
\text { curasoae } \\
\text { yerbabuenae }\end{array}$ & Bat, Lesser Long-nosed & 1 & ENDANGERED & 80 & Mixed Forest & $n / a$ \\
\hline $\begin{array}{l}\text { Lilaeopsis } \\
\text { schaffneriana var. } \\
\text { recurva }\end{array}$ & Water-umbel, Huachuca & 1 & ENDANGERED & 0.0001 & Evergreen Forest & PFO \\
\hline $\begin{array}{l}\text { Lycaeides melissa } \\
\text { samuelis }\end{array}$ & Butterfly, Karner Blue & 1 & ENDANGERED & 4 & Mixed Forest & $\mathrm{n} / \mathrm{a}$ \\
\hline Lynx canadensis & Lynx, Canada & 1 & THREATENED & 100 & Evergreen Forest & $n / a$ \\
\hline $\begin{array}{l}\text { Lysimachia } \\
\text { asperulaefolia }\end{array}$ & Loosestrife, Rough-leaved & 2 & ENDANGERED & 0.0001 & Woody Wetlands & PFO, PSS \\
\hline
\end{tabular}




\begin{tabular}{|c|c|c|c|c|c|c|}
\hline Scientific Name & Common Name & $\begin{array}{l}\text { Number of } \\
\text { Installations }\end{array}$ & Listing Status & $\begin{array}{l}\text { Distance } \\
(\mathrm{km})\end{array}$ & NLCD Habitat & NWI Habitat \\
\hline Meda fulgida & Spikedace & 1 & ENDANGERED & 10 & Open Water & $\begin{array}{l}\text { R3UB1, } \\
\text { R3UB2, R3SB2, } \\
\text { R3SB3, R3SB4, } \\
\text { PUS1, PUS2 }\end{array}$ \\
\hline Mycteria americana & Stork, Wood & 3 & ENDANGERED & 100 & Emergent Herbaceous Wetlands & $n / a$ \\
\hline Myotis grisescens & Bat, Gray & 5 & ENDANGERED & 92 & Mixed Forest & $n / a$ \\
\hline Myotis septentrionalis & Bat, Northern Long-eared & 32 & THREATENED & 100 & $\begin{array}{l}\text { Deciduous Forest, Evergreen } \\
\text { Forest, Mixed Forest, Woody } \\
\text { Wetlands }\end{array}$ & $n / a$ \\
\hline Myotis sodalis & Bat, Indiana & 8 & ENDANGERED & $55-80$ & Mixed Forest & $n / a$ \\
\hline $\begin{array}{l}\text { Neonympha mitchellii } \\
\text { francisci }\end{array}$ & Butterfly, Saint Francis' Satyr & 1 & ENDANGERED & 2 & $\begin{array}{l}\text { Deciduous Forest, Mixed Forest, } \\
\text { Woody Wetlands }\end{array}$ & PEM1D \\
\hline $\begin{array}{l}\text { Nicrophorus } \\
\text { americanus }\end{array}$ & $\begin{array}{l}\text { Beetle, American Burying (Except, } \\
\text { where listed as experimental } \\
\text { population) }\end{array}$ & 3 & ENDANGERED & 1 & $\begin{array}{l}\text { Deciduous Forest, Evergreen } \\
\text { Forest, Grassland/Herbaceous }\end{array}$ & $n / a$ \\
\hline $\begin{array}{l}\text { Notropis topeka } \\
\text { (=tristis) }\end{array}$ & Shiner, Topeka & 1 & ENDANGERED & 10 & Open Water & R3 \\
\hline $\begin{array}{l}\text { Oncorhynchus } \\
\text { (=Salmo) mykiss }\end{array}$ & $\begin{array}{l}\text { Steelhead (southern CA coast) (All } \\
\text { naturally spawned populations [and } \\
\text { their progeny] in rivers from the } \\
\text { Santa Maria R., San Luis Obispo } \\
\text { County, CA [inclusive] to Malibu Cr., } \\
\text { Los Angeles County, CA [inclusive]) }\end{array}$ & 1 & ENDANGERED & 1500 & Open Water & $E, R$ \\
\hline $\begin{array}{l}\text { Oncorhynchus } \\
\text { (=Salmo) tshawytscha }\end{array}$ & $\begin{array}{l}\text { Salmon, Chinook (Puget Sound } \\
\text { ESU, including all naturally spawned } \\
\text { populations from rivers/streams } \\
\text { flowing into Puget Sound including } \\
\text { the Straits of Juan De Fuca from the } \\
\text { Elwha R, eastward; rivers/streams } \\
\text { flowing into Hood Canal, South \& } \\
\text { North Sound;Strait of Georgia; and } \\
26 \text { propagation programs) }\end{array}$ & 1 & THREATENED & 1500 & Open Water & $E, R$ \\
\hline Panthera onca & Jaguar & 2 & ENDANGERED & 30 & Evergreen Forest & $n / a$ \\
\hline Percina aurora & Darter, Pearl & 1 & THREATENED & 10 & Open Water & R2UB, R3RB \\
\hline Percina rex & Logperch, Roanoke & 1 & ENDANGERED & 10 & Open Water & $\begin{array}{l}\text { R3RB2, } \\
\text { R3UB1, R3UB2 }\end{array}$ \\
\hline Picoides borealis & Woodpecker, Red-cockaded & 8 & ENDANGERED & 5 & Evergreen Forest & $n / a$ \\
\hline $\begin{array}{l}\text { Pituophis } \\
\text { melanoleucus lodingi }\end{array}$ & Pinesnake, Black & 1 & THREATENED & 0.338 & Evergreen Forest & $n / a$ \\
\hline Pituophis ruthveni & Pinesnake, Louisiana & 1 & THREATENED & 0.163 & Evergreen Forest & $n / a$ \\
\hline $\begin{array}{l}\text { Pleurobema } \\
\text { strodeanum }\end{array}$ & Pigtoe, Fuzzy & 1 & THREATENED & 2 & Open Water & R2UB2 \\
\hline $\begin{array}{l}\text { Poeciliopsis } \\
\text { occidentalis } \\
\text { occidentalis }\end{array}$ & Topminnow, Gila & 1 & ENDANGERED & 10 & Emergent Herbaceous Wetlands & $P$ \\
\hline
\end{tabular}




\begin{tabular}{|c|c|c|c|c|c|c|}
\hline Scientific Name & Common Name & $\begin{array}{l}\text { Number of } \\
\text { Installations }\end{array}$ & Listing Status & $\begin{array}{l}\text { Distance } \\
(\mathrm{km})\end{array}$ & NLCD Habitat & NWI Habitat \\
\hline Rana chiricahuensis & Frog, Chiricahua Leopard & 1 & THREATENED & 0.5 & Emergent Herbaceous Wetlands & $\mathrm{P}$ \\
\hline Rana draytonii & Frog, California Red-legged & 2 & THREATENED & 1.6 & Emergent Herbaceous Wetlands & $\mathrm{P}, \mathrm{R} 3, \mathrm{R} 4$ \\
\hline Rana pretiosa & Frog, Oregon Spotted & 1 & THREATENED & 0.5 & Emergent Herbaceous Wetlands & $\mathrm{P}$ \\
\hline $\begin{array}{l}\text { Rhododendron } \\
\text { chapmanii }\end{array}$ & Rhododendron, Chapman & 1 & ENDANGERED & 0.002 & Woody Wetlands & PSS \\
\hline Rhus michauxii & Sumac, Michaux's & 2 & ENDANGERED & 0.04 & Evergreen Forest & $\mathrm{n} / \mathrm{a}$ \\
\hline Salvelinus confluentus & $\begin{array}{l}\text { Trout, Bull (contiguous, [lower } 48 \\
\text { states]) }\end{array}$ & 1 & THREATENED & 100 & Open Water & L, R \\
\hline Schwalbea americana & Chaffseed, American & 1 & ENDANGERED & 0.002 & Evergreen Forest & $\mathrm{n} / \mathrm{a}$ \\
\hline Scutellaria montana & Skullcap, Large-flowered & 1 & THREATENED & 0.001 & Deciduous Forest & $\mathrm{n} / \mathrm{a}$ \\
\hline $\begin{array}{l}\text { Setophage kirlandii } \\
\text { (=Dendroica kirtlandii) }\end{array}$ & Warbler, Kirtland's & 1 & ENDANGERED & 5 & Evergreen Forest & $\mathrm{n} / \mathrm{a}$ \\
\hline Sistrurus catenatus & Massasauga & 4 & THREATENED & 0.1 & Woody Wetlands & PFO, PSS \\
\hline Solidago houghtonii & Goldenrod, Houghton's & 1 & THREATENED & 0.01 & Emergent Herbaceous Wetlands & PEM \\
\hline Spiranthes delitescens & Ladies'-tresses, Canelo Hills & 1 & ENDANGERED & 0.01 & Emergent Herbaceous Wetlands & PEM \\
\hline $\begin{array}{l}\text { Strix occidentalis } \\
\text { caurina }\end{array}$ & Owl, Northern Spotted & 1 & THREATENED & 23 & Evergreen Forest & $\mathrm{n} / \mathrm{a}$ \\
\hline $\begin{array}{l}\text { Strix occidentalis } \\
\text { lucida }\end{array}$ & Owl, Mexican Spotted & 3 & THREATENED & 22 & Evergreen Forest & $\mathrm{n} / \mathrm{a}$ \\
\hline $\begin{array}{l}\text { Thamnophis eques } \\
\text { megalops }\end{array}$ & Gartersnake, Northern Mexican & 1 & THREATENED & 2 & Evergreen Forest & $\mathrm{n} / \mathrm{a}$ \\
\hline $\begin{array}{l}\text { Thomomys mazama } \\
\text { glacialis }\end{array}$ & Pocket gopher, Roy Prairie & 1 & THREATENED & 0.01 & Grassland/Herbaceous & $\mathrm{n} / \mathrm{a}$ \\
\hline Trifolium stoloniferum & Clover, Running Buffalo & 1 & ENDANGERED & 0.04 & Deciduous Forest & $\mathrm{n} / \mathrm{a}$ \\
\hline Trillium reliquum & Trillium, Relict & 1 & ENDANGERED & 0.002 & Evergreen Forest & $\mathrm{n} / \mathrm{a}$ \\
\hline Villosa choctawensis & Bean, Choctaw & 1 & ENDANGERED & 2 & Open Water & R2UB2 \\
\hline Villosa fabalis & Bean, Rayed & 1 & ENDANGERED & 2 & Open Water & PSS6, R4SB2 \\
\hline Vireo atricapilla & Vireo, Black-capped & 3 & ENDANGERED & 3.6 & Shrub/Scrub & $\mathrm{n} / \mathrm{a}$ \\
\hline Vireo bellii pusillus & Vireo, Least Bell's & 1 & ENDANGERED & 20 & Deciduous Forest & PFO \\
\hline $\begin{array}{l}\text { Vulpes macrotis } \\
\text { mutica }\end{array}$ & Fox, San Joaquin Kit & 2 & ENDANGERED & 7.8 & Shrub/Scrub & $\mathrm{n} / \mathrm{a}$ \\
\hline $\begin{array}{l}\text { Zapus hudsonius } \\
\text { luteus }\end{array}$ & $\begin{array}{l}\text { Mouse, New Mexico Meadow } \\
\text { Jumping }\end{array}$ & 1 & ENDANGERED & 0.05 & Grassland & $\mathrm{n} / \mathrm{a}$ \\
\hline
\end{tabular}


Table A2. Occurrence of 84 federally listed species on 54 CONUS Army and Army National Guard Installations.

\begin{tabular}{|c|c|c|}
\hline State & Installation & Common Name \\
\hline MD & $\begin{array}{l}\text { ABERDEEN PROVING } \\
\text { GROUND }\end{array}$ & Bat, Northern Long-eared \\
\hline IN & CAMP ATTERBURY & $\begin{array}{l}\text { Bat, Indiana } \\
\text { Bat, Northern Long-eared } \\
\text { Bean, Rayed } \\
\text { Mussel, Snuffbox }\end{array}$ \\
\hline TX & CAMP BOWIE & Vireo, Black-capped \\
\hline WV & CAMP DAWSON & $\begin{array}{l}\text { Bat, Indiana } \\
\text { Bat, Northern Long-eared } \\
\text { Clover, Running Buffalo }\end{array}$ \\
\hline ND & CAMP GRAFTON & Bat, Northern Long-eared \\
\hline OK & CAMP GRUBER & $\begin{array}{l}\text { Bat, Northern Long-eared } \\
\text { Beetle, American Burying (except where } \\
\text { listed as experimental population) }\end{array}$ \\
\hline TX & CAMP MAXEY & $\begin{array}{l}\text { Beetle, American Burying (Except, where } \\
\text { listed as experimental population) }\end{array}$ \\
\hline \multirow{2}{*}{$A Z$} & CAMP NAVAJO & Owl, Mexican Spotted \\
\hline & CAMP RAVENNA ARNG JMTC & Bat, Northern Long-eared \\
\hline MN & CAMP RIPLEY & $\begin{array}{l}\text { Bat, Northern Long-eared } \\
\text { Lynx, Canada }\end{array}$ \\
\hline CA & CAMP SAN LOUIS OBISPO & Frog, California Red-legged \\
\hline MI & $\begin{array}{l}\text { CTC FORT CUSTER TRNG } \\
\text { CENTER }\end{array}$ & $\begin{array}{l}\text { Bat, Northern Long-eared } \\
\text { Massasauga }\end{array}$ \\
\hline UT & DUGWAY PROVING GROUND & Rabbit, Pygmy (Columbia Basin DPS) \\
\hline VA & FORT A P HILL & $\begin{array}{l}\text { Bat, Northern Long-eared } \\
\text { Pink, Swamp } \\
\text { Pogonia, Small Whorled }\end{array}$ \\
\hline GA & FORT BENNING & $\begin{array}{l}\text { Bat, Northern Long-eared } \\
\text { Stork, Wood } \\
\text { Trillium, Relict } \\
\text { Woodpecker, Red-cockaded }\end{array}$ \\
\hline TX & FORT BLISS & Cactus, Sneed Pincushion \\
\hline
\end{tabular}




\begin{tabular}{|c|c|c|}
\hline State & Installation & Common Name \\
\hline NC & FORT BRAGG & $\begin{array}{l}\text { Bat, Northern Long-eared } \\
\text { Butterfly, Saint Francis' Satyr } \\
\text { Chaffseed, American } \\
\text { Loosestrife, Rough-leaved } \\
\text { Sumac, Michaux's } \\
\text { Woodpecker, Red-cockaded }\end{array}$ \\
\hline TN & FORT CAMPBELL & $\begin{array}{l}\text { Bat, Gray } \\
\text { Bat, Indiana } \\
\text { Bat, Northern Long-eared }\end{array}$ \\
\hline & FORT CARSON & Owl, Mexican Spotted \\
\hline $\mathrm{CO}$ & FORT CHAFFEE ARNG MTC & $\begin{array}{l}\text { Beetle, American Burying (except where } \\
\text { listed as experimental population) } \\
\text { Geocarpon }\end{array}$ \\
\hline NJ & FORT DIX & Bat, Northern Long-eared \\
\hline \multirow[t]{2}{*}{ NY } & FORT DRUM & $\begin{array}{l}\text { Bat, Indiana } \\
\text { Bat, Northern Long-eared }\end{array}$ \\
\hline & FORT EUSTIS & Bat, Northern Long-eared \\
\hline GA & FORT GORDON & $\begin{array}{l}\text { Bat, Gray } \\
\text { Bat, Northern Long-eared } \\
\text { Woodpecker, Red-cockaded }\end{array}$ \\
\hline $\mathrm{TX}$ & FORT HOOD & $\begin{array}{l}\text { Vireo, Black-capped } \\
\text { Warbler, Golden-cheeked }\end{array}$ \\
\hline$A Z$ & FORT HUACHUCA & $\begin{array}{l}\text { Topminnow, Gila } \\
\text { Bat, Lesser Long-nosed } \\
\text { Chub, Gila } \\
\text { Flycatcher, Southwestern Willow } \\
\text { Frog, Chiricahua Leopard } \\
\text { Gartersnake, Northern Mexican } \\
\text { Jaguar } \\
\text { Ladies'-tresses, Canelo Hills } \\
\text { Ocelot } \\
\text { Owl, Mexican Spotted } \\
\text { Pupfish, Desert } \\
\text { Salamander, Sonora Tiger } \\
\text { Spikedace } \\
\text { Water umbel, Huachuca }\end{array}$ \\
\hline
\end{tabular}




\begin{tabular}{|c|c|c|}
\hline State & Installation & Common Name \\
\hline CA & FORT HUNTER LIGGETT & $\begin{array}{l}\text { Amole, Purple } \\
\text { Condor, California (entire except where } \\
\text { listed as experimental populations) } \\
\text { Fairy shrimp, Vernal Pool } \\
\text { Fox, San Joaquin Kit } \\
\text { Salamander, California Tiger (Central CA } \\
\text { DPS, not including Santa Barbara and } \\
\text { Sonoma DPS) } \\
\text { Toad, Arroyo } \\
\text { Vireo, Least Bell's }\end{array}$ \\
\hline PA & FORT INDIANTOWN GAP & Bat, Northern Long-eared \\
\hline SC & FORT JACKSON & $\begin{array}{l}\text { Bat, Northern Long-eared } \\
\text { Coneflower, Smooth } \\
\text { Loosestrife, Rough-leaved } \\
\text { Woodpecker, Red-cockaded }\end{array}$ \\
\hline KY & FORT KNOX & $\begin{array}{l}\text { Bat, Gray } \\
\text { Bat, Indiana } \\
\text { Bat, Northern Long-eared }\end{array}$ \\
\hline VA & FORT LEE & Bat, Northern Long-eared \\
\hline MO & FORT LEONARD WOOD & $\begin{array}{l}\text { Bat, Gray } \\
\text { Bat, Indiana } \\
\text { Bat, Northern Long-eared } \\
\text { Spectaclecase }\end{array}$ \\
\hline WI & FORT MCCOY & $\begin{array}{l}\text { Bat, Northern Long-eared } \\
\text { Bumble Bee, Rusty Patched } \\
\text { Butterfly, Karner Blue } \\
\text { Massasauga }\end{array}$ \\
\hline VA & FORT PICKETT ARNG MTC & $\begin{array}{l}\text { Bat, Northern Long-eared } \\
\text { Lance, Yellow } \\
\text { Logperch, Roanoke } \\
\text { Sumac, Michaux's }\end{array}$ \\
\hline LA & FORT POLK & $\begin{array}{l}\text { Bat, Northern Long-eared } \\
\text { Pinesnake, Louisiana } \\
\text { Woodpecker, Red-cockaded }\end{array}$ \\
\hline
\end{tabular}




\begin{tabular}{|c|c|c|}
\hline State & Installation & Common Name \\
\hline MN & FORT RILEY & $\begin{array}{l}\text { Bat, Northern Long-eared } \\
\text { Plover, Piping (all areas except Great } \\
\text { Lakes watershed of IL, IN, MI, MN, NY, } \\
\text { OH, PA, and WI) } \\
\text { Shiner, Topeka }\end{array}$ \\
\hline$A L$ & FORT RUCKER & $\begin{array}{l}\text { Bean, Choctaw } \\
\text { Pigtoe, Fuzzy }\end{array}$ \\
\hline OK & FORT SILL & Vireo, Black-capped \\
\hline GA & FORT STEWART & $\begin{array}{l}\text { Coneflower, Smooth } \\
\text { Salamander, Frosted Flatwoods } \\
\text { Snake, Eastern Indigo } \\
\text { Stork, Wood } \\
\text { Sturgeon, Atlantic (South Atlantic DPS) } \\
\text { Sturgeon, Shortnose } \\
\text { Woodpecker, Red-cockaded }\end{array}$ \\
\hline WA & $\begin{array}{l}\text { JOINT BASE LEWIS- } \\
\text { MCCHORD }\end{array}$ & $\begin{array}{l}\text { Butterfly, Taylor's Checkerspot } \\
\text { Frog, Oregon Spotted } \\
\text { Horned Lark, Streaked } \\
\text { Howellia, Water } \\
\text { Owl, Northern Spotted } \\
\text { Pocket gopher, Roy Prairie } \\
\text { Salmon, Chinook (Puget Sound ESU, } \\
\text { including all naturally spawned } \\
\text { populations from rivers/streams flowing } \\
\text { into Puget Sound including the Straits of } \\
\text { Juan De Fuca from the Elwha R, } \\
\text { eastward; rivers/streams flowing into } \\
\text { Hood Canal, South \& North Sound; Strait } \\
\text { of Georgia; and } 26 \text { propagation } \\
\text { programs) } \\
\text { Trout, Bull (contiguous [lower } 48 \text { states]) }\end{array}$ \\
\hline IA & MACON TRAINING SITE & Bat, Indiana \\
\hline IL & MARSEILLES TC & $\begin{array}{l}\text { Bat, Northern Long-eared } \\
\text { Bumble Bee, Rusty Patched } \\
\text { Massasauga }\end{array}$ \\
\hline MA & MTA CAMP EDWARDS & Bat, Northern Long-eared \\
\hline
\end{tabular}




\begin{tabular}{|c|c|c|}
\hline State & Installation & Common Name \\
\hline MS & MTA CAMP SHELBY & $\begin{array}{l}\text { Darter, Pearl } \\
\text { Pinesnake, Black } \\
\text { Quillwort, Louisiana } \\
\text { Tortoise, Gopher (Wherever found west of } \\
\text { Mobile and Tombigbee Rivers in AL, MS, } \\
\text { and LA) } \\
\text { Woodpecker, Red-cockaded }\end{array}$ \\
\hline $\mathrm{FL}$ & MTC CAMP BLANDING & $\begin{array}{l}\text { Rhododendron, Chapman } \\
\text { Scrub-jay, Florida } \\
\text { Snake, Eastern Indigo } \\
\text { Stork, Wood } \\
\text { Woodpecker, Red-cockaded }\end{array}$ \\
\hline MI & MTC-H CAMP GRAYLING & $\begin{array}{l}\text { Bat, Northern Long-eared } \\
\text { Goldenrod, Houghton's } \\
\text { Massasauga } \\
\text { Warbler, Kirtland's }\end{array}$ \\
\hline $\mathrm{CA}$ & MTC-H CAMP ROBERTS & $\begin{array}{l}\text { Amole, Purple } \\
\text { Fairy shrimp, Vernal Pool } \\
\text { Fox, San Joaquin Kit } \\
\text { Steelhead (southern CA coast) (All } \\
\text { naturally spawned populations [and their } \\
\text { progeny] in rivers from the Santa Maria } \\
\text { R., San Luis Obispo County, CA [inclusive] } \\
\text { to Malibu Cr., Los Angeles County, CA } \\
\text { [inclusive]) }\end{array}$ \\
\hline $\mathrm{CA}$ & $\begin{array}{l}\text { NATIONAL TRAINING } \\
\text { CENTER AND FORT IRWIN }\end{array}$ & $\begin{array}{l}\text { Milk-vetch, Lane Mountain } \\
\text { Tortoise, Desert (except AZ south and } \\
\text { east of Colorado River, and Mexico) }\end{array}$ \\
\hline VT & NG TS ETHAN ALLEN RANGE & Bat, Northern Long-eared \\
\hline ID & ORCHARD TA & Peppergrass, Slickspot \\
\hline $\mathrm{CA}$ & PARKS RFTA & $\begin{array}{l}\text { Frog, California Red-legged } \\
\text { Salamander, California Tiger (Central CA } \\
\text { DPS, not including Santa Barbara and } \\
\text { Sonoma DPS) }\end{array}$ \\
\hline GA & VTS CATOOSA & $\begin{array}{l}\text { Bat, Gray } \\
\text { Bat, Northern Long-eared } \\
\text { Skullcap, Large-flowered }\end{array}$ \\
\hline
\end{tabular}




\begin{tabular}{|l|l|l|}
\hline State & Installation & Common Name \\
\hline NY & $\begin{array}{l}\text { WEST POINT MILITARY } \\
\text { RESERVATION }\end{array}$ & $\begin{array}{l}\text { Bat, Indiana } \\
\text { Bat, Northern Long-eared }\end{array}$ \\
\hline NM & $\begin{array}{l}\text { WHITE SANDS MISSILE } \\
\text { RANGE }\end{array}$ & $\begin{array}{l}\text { Cuckoo, Yellow-billed Western Population } \\
\text { Segment } \\
\text { Flycatcher, Southwestern Willow } \\
\text { Jaguar } \\
\text { Mouse, New Mexico Meadow Jumping } \\
\text { Pennyroyal, Todsen's }\end{array}$ \\
\hline
\end{tabular}


Table A3. Comprehensive list of relative network conservation values for species networks at installations.

\begin{tabular}{|c|c|c|}
\hline Installation & Species & $\begin{array}{l}\text { Relative Network } \\
\text { Conservation Value }\end{array}$ \\
\hline Fort Huachuca & Lesser Long-Nosed Bat & 0.6 \\
\hline Fort Huachuca & Mexican Spotted Owl & 0.6 \\
\hline Fort Huachuca & Jaguar & 0.6 \\
\hline Fort Huachuca & $\begin{array}{l}\text { Northern Mexican } \\
\text { Gartersnake }\end{array}$ & 0.6 \\
\hline Fort Huachuca & Ocelot & 0.5 \\
\hline MTC Camp Blanding & $\begin{array}{l}\text { Western Yellow-billed } \\
\text { Cuckoo }\end{array}$ & 0.5 \\
\hline Fort Huachuca & Huachuca Water-Umbel & 0.5 \\
\hline MTC-H Camp Grayling & Kirtland's Warbler & 0.5 \\
\hline Camp Navajo & Mexican Spotted Owl & 0.5 \\
\hline Joint Base Lewis-McChord & Northern Spotted Owl & 0.5 \\
\hline MTC Camp Blanding & Wood Stork & 0.5 \\
\hline Fort Huachuca & $\begin{array}{l}\text { Southwestern Willow } \\
\text { Flycatcher }\end{array}$ & 0.5 \\
\hline $\begin{array}{l}\text { White Sands Missile } \\
\text { Range }\end{array}$ & $\begin{array}{l}\text { Southwestern Willow } \\
\text { Flycatcher }\end{array}$ & 0.4 \\
\hline Dugway Proving Ground & Pygmy Rabbit & 0.4 \\
\hline Fort Leonard Wood & Gray Bat & 0.4 \\
\hline Fort Stewart & Wood Stork & 0.4 \\
\hline Fort Hunter Liggett & Vernal Pool Fairy Shrimp & 0.4 \\
\hline MTC-H Camp Roberts & Vernal Pool Fairy Shrimp & 0.4 \\
\hline Fort Hunter Liggett & Purple Amole & 0.4 \\
\hline MTC-H Camp Roberts & Purple Amole & 0.4 \\
\hline Fort Dix & Northern Long-eared Bat & 0.4 \\
\hline MTC-H Camp Roberts & San Joaquin Kit Fox & 0.4 \\
\hline Fort Hunter Liggett & San Joaquin Kit Fox & 0.4 \\
\hline Fort Huachuca & $\begin{array}{l}\text { Canelo Hills Ladies'- } \\
\text { Tresses }\end{array}$ & 0.4 \\
\hline
\end{tabular}




\begin{tabular}{|c|c|c|}
\hline Installation & Species & $\begin{array}{l}\text { Relative Network } \\
\text { Conservation Value }\end{array}$ \\
\hline Fort Huachuca & Northern Aplomado Falcon & 0.4 \\
\hline MTC-H Camp Grayling & Northern Long-eared Bat & 0.4 \\
\hline Fort Hunter Liggett & Least Bell's Vireo & 0.4 \\
\hline Fort Carson & Mexican Spotted Owl & 0.4 \\
\hline Fort Huachuca & Gila Chub & 0.4 \\
\hline Fort Huachuca & Chiricahua Leopard Frog & 0.4 \\
\hline Fort Huachuca & Gila Topminnow & 0.4 \\
\hline Fort Huachuca & Desert Pupfish & 0.4 \\
\hline Fort Drum & Northern Long-eared Bat & 0.4 \\
\hline Fort Drum & Indiana Bat & 0.4 \\
\hline Joint Base Lewis-McChord & Oregon Spotted Frog & 0.4 \\
\hline Fort Hunter Liggett & $\begin{array}{l}\text { California Tiger } \\
\text { Salamander }\end{array}$ & 0.4 \\
\hline MTC-H Camp Grayling & Massasauga & 0.4 \\
\hline $\begin{array}{l}\text { West Point Military } \\
\text { Reservation }\end{array}$ & Indiana Bat & 0.4 \\
\hline VTS Catoosa & Large-flowered Skullcap & 0.4 \\
\hline Fort Leonard Wood & Northern Long-eared Bat & 0.4 \\
\hline Camp Gruber & Northern Long-eared Bat & 0.4 \\
\hline Fort Leonard Wood & Indiana Bat & 0.4 \\
\hline Joint Base Lewis-McChord & Streaked Horned Lark & 0.4 \\
\hline MTC-H Camp Grayling & Houghton's Goldenrod & 0.3 \\
\hline Fort McCoy & Massasauga & 0.3 \\
\hline $\begin{array}{l}\text { West Point Military } \\
\text { Reservation }\end{array}$ & Northern Long-eared Bat & 0.3 \\
\hline Fort McCoy & Karner Blue Butterfly & 0.3 \\
\hline VTS Catoosa & Northern Long-eared Bat & 0.3 \\
\hline Camp San Luis Obispo & California Red-legged Frog & 0.3 \\
\hline Joint Base Lewis-McChord & Water Howellia & 0.3 \\
\hline
\end{tabular}




\begin{tabular}{|c|c|c|}
\hline Installation & Species & $\begin{array}{l}\text { Relative Network } \\
\text { Conservation Value }\end{array}$ \\
\hline Fort Bragg & Rough-leaved Loosestrife & 0.3 \\
\hline Joint Base Lewis-McChord & Chinook Salmon & 0.3 \\
\hline MTA Camp Edwards & Northern Long-eared Bat & 0.3 \\
\hline Fort McCoy & Northern Long-eared Bat & 0.3 \\
\hline Camp Gruber & American Burying Beetle & 0.3 \\
\hline Joint Base Lewis-McChord & Bull Trout & 0.3 \\
\hline MTC Camp Blanding & Eastern Indigo Snake & 0.3 \\
\hline MTC Camp Blanding & $\begin{array}{l}\text { Red-cockaded } \\
\text { Woodpecker }\end{array}$ & 0.3 \\
\hline Fort McCoy & $\begin{array}{l}\text { Rusty Patched Bumble } \\
\text { Bee }\end{array}$ & 0.3 \\
\hline Fort A. P. Hill & Swamp Pink & 0.3 \\
\hline MTC-H Camp Roberts & Steelhead & 0.3 \\
\hline Camp Dawson & Northern Long-eared Bat & 0.3 \\
\hline Fort Hunter Liggett & Arroyo Toad & 0.3 \\
\hline MTA Camp Shelby & Louisiana Quillwort & 0.3 \\
\hline Fort Stewart & $\begin{array}{l}\text { Red-cockaded } \\
\text { Woodpecker }\end{array}$ & 0.3 \\
\hline Fort Stewart & Eastern Indigo Snake & 0.3 \\
\hline MTA Camp Shelby & Pearl Darter & 0.3 \\
\hline VTS Catoosa & Gray Bat & 0.3 \\
\hline Fort Benning & Wood Stork & 0.3 \\
\hline $\begin{array}{l}\text { White Sands Missile } \\
\text { Range }\end{array}$ & $\begin{array}{l}\text { New Mexico Jumping } \\
\text { Mouse }\end{array}$ & 0.3 \\
\hline Marseilles Training Center & Massasauga & 0.3 \\
\hline Camp Dawson & Indiana Bat & 0.3 \\
\hline Fort Polk & Louisiana Pine Snake & 0.3 \\
\hline Fort Polk & $\begin{array}{l}\text { Red-cockaded } \\
\text { Woodpecker }\end{array}$ & 0.3 \\
\hline Marseilles Training Center & Northern Long-eared Bat & 0.3 \\
\hline
\end{tabular}




\begin{tabular}{|c|c|c|}
\hline Installation & Species & $\begin{array}{l}\text { Relative Network } \\
\text { Conservation Value }\end{array}$ \\
\hline Marseilles Training Center & $\begin{array}{l}\text { Rusty Patched Bumble } \\
\text { Bee }\end{array}$ & 0.3 \\
\hline Camp Atterbury & Rayed Bean & 0.3 \\
\hline Camp Ripley & Canada Lynx & 0.3 \\
\hline Camp Dawson & Running Buffalo Clover & 0.3 \\
\hline Camp Atterbury & Indiana Bat & 0.3 \\
\hline Camp Atterbury & Northern Long-eared Bat & 0.3 \\
\hline MTC Camp Blanding & Chapman Rhododendron & 0.3 \\
\hline Fort Benning & Choctaw Bean & 0.3 \\
\hline Fort Benning & Fuzzy Pigtoe & 0.3 \\
\hline Fort Polk & Northern Long-eared Bat & 0.3 \\
\hline NG TS Ethan Allen Range & Northern Long-eared Bat & 0.3 \\
\hline Aberdeen Proving Ground & Northern Long-eared Bat & 0.3 \\
\hline Fort Indiantown Gap & Northern Long-eared Bat & 0.3 \\
\hline Parks RFTA & California Red-legged Frog & 0.3 \\
\hline Parks RFTA & $\begin{array}{l}\text { California Tiger } \\
\text { Salamander }\end{array}$ & 0.3 \\
\hline Fort Stewart & Atlantic Sturgeon & 0.3 \\
\hline Fort Stewart & Shortnose Sturgeon & 0.3 \\
\hline Fort Benning & Northern Long-eared Bat & 0.3 \\
\hline Camp Ripley & Northern Long-eared Bat & 0.3 \\
\hline MTC Camp Blanding & Florida Scrub Jay & 0.3 \\
\hline Fort Knox & Northern Long-eared Bat & 0.3 \\
\hline MTA Camp Shelby & Black Pinesnake & 0.3 \\
\hline MTA Camp Shelby & Gopher Tortoise & 0.3 \\
\hline MTA Camp Shelby & $\begin{array}{l}\text { Red-cockaded } \\
\text { Woodpecker }\end{array}$ & 0.3 \\
\hline Fort Knox & Indiana Bat & 0.3 \\
\hline Fort Hunter Liggett & California Condor & 0.3 \\
\hline
\end{tabular}




\begin{tabular}{|c|c|c|}
\hline Installation & Species & $\begin{array}{l}\text { Relative Network } \\
\text { Conservation Value }\end{array}$ \\
\hline $\begin{array}{l}\text { Ravenna Training and Log } \\
\text { Site }\end{array}$ & Northern Long-eared Bat & 0.3 \\
\hline Fort A. P. Hill & Northern Long-eared Bat & 0.3 \\
\hline Fort Eustis & Northern Long-eared Bat & 0.3 \\
\hline Fort Lee & Northern Long-eared Bat & 0.3 \\
\hline Fort Pickett, ARNG MTC & Northern Long-eared Bat & 0.3 \\
\hline Fort Stewart & Smooth Coneflower & 0.3 \\
\hline Fort Stewart & $\begin{array}{l}\text { Frosted Flatwoods } \\
\text { Salamander }\end{array}$ & 0.3 \\
\hline Fort Knox & Gray Bat & 0.3 \\
\hline Fort Bragg & $\begin{array}{l}\text { Red-cockaded } \\
\text { Woodpecker }\end{array}$ & 0.3 \\
\hline Macon Training Site & Indiana Bat & 0.3 \\
\hline Fort Jackson & Rough-leaved Loosestrife & 0.3 \\
\hline Fort Campbell & Gray Bat & 0.3 \\
\hline Fort Campbell & Northern Long-eared Bat & 0.3 \\
\hline Fort Campbell & Indiana Bat & 0.3 \\
\hline Fort Gordon & $\begin{array}{l}\text { Red-cockaded } \\
\text { Woodpecker }\end{array}$ & 0.3 \\
\hline Fort Jackson & $\begin{array}{l}\text { Red-cockaded } \\
\text { Woodpecker }\end{array}$ & 0.3 \\
\hline Fort Bragg & Northern Long-eared Bat & 0.3 \\
\hline Fort Gordon & Northern Long-eared Bat & 0.3 \\
\hline Fort Jackson & Northern Long-eared Bat & 0.3 \\
\hline Camp Maxey & American Burying Beetle & 0.3 \\
\hline Fort Bragg & St. Francis Satyr & 0.3 \\
\hline Fort A. P. Hill & Small Whorled Pogonia & 0.3 \\
\hline Fort Custer & Northern Long-eared Bat & 0.3 \\
\hline Fort Leonard Wood & Spectaclecase & 0.3 \\
\hline Fort Huachuca & Spikedace & 0.3 \\
\hline
\end{tabular}




\begin{tabular}{|l|l|c|}
\hline Installation & Species & $\begin{array}{l}\text { Relative Network } \\
\text { Conservation Value }\end{array}$ \\
\hline Fort Huachuca & Sonora Tiger Salamander & 0.3 \\
\hline Fort Pickett ARNG MTC & Yellow Lance & 0.3 \\
\hline Fort Pickett, ARNG MTC & Roanoke Logperch & 0.3 \\
\hline Camp Grafton & Northern Long-eared Bat & 0.3 \\
\hline Fort Pickett, ARNG MTC & Michaux's Sumac & 0.3 \\
\hline Fort Gordon & Gray Bat & 0.3 \\
\hline Fort Custer & Massasauga & 0.3 \\
\hline Camp Atterbury & Snuffbox Mussel & 0.3 \\
\hline Fort Chaffee Maneuver & Geocarpon & 0.3 \\
\hline Training Center & & 0.3 \\
\hline Fort Jackson & Smooth Coneflower & 0.3 \\
\hline Fort Sill & Black-capped Vireo & 0.3 \\
\hline Fort Riley & Piping Plover & 0.3 \\
\hline Fort Riley & Northern Long-eared Bat & 0.3 \\
\hline Fort Hood & Golden-cheeked Warbler & 0.3 \\
\hline Fort Hood & Black-capped Vireo & 0.3 \\
\hline Fort Riley & Oregon Silverspot & 0.3 \\
\hline Camp Rilea & Michaux's Sumac & 0.3 \\
\hline Fort Bragg & & 0.3 \\
\hline Fort Bragg & Mmerican Chaffseed & 0.3 \\
\hline
\end{tabular}


Table A4. Percentage of habitat networks in

public, private conservation, and other private lands.

\begin{tabular}{|c|c|c|c|c|}
\hline Installation & Species & $\begin{array}{l}\text { Percent Public } \\
\text { Lands }\end{array}$ & $\begin{array}{l}\text { Percent Private } \\
\text { Conservation } \\
\text { Lands }\end{array}$ & $\begin{array}{l}\text { Percent Other } \\
\text { Private Lands }\end{array}$ \\
\hline Fort Huachuca & $\begin{array}{l}\text { Lesser Long- } \\
\text { nosed Bat }\end{array}$ & 99.1 & 0.0 & 0.9 \\
\hline Fort Huachuca & $\begin{array}{l}\text { Mexican } \\
\text { Spotted Owl, } \\
\text { Northern } \\
\text { Mexican } \\
\text { Gartersnake, } \\
\text { Jaguar }\end{array}$ & 97.2 & 0.0 & 2.8 \\
\hline Fort Huachuca & Ocelot & 97.1 & 0.4 & 2.5 \\
\hline Fort Bliss & $\begin{array}{l}\text { Sneed } \\
\text { Pincushion } \\
\text { Cactus }\end{array}$ & 95.1 & 1.1 & 3.9 \\
\hline Camp Navajo & $\begin{array}{l}\text { Mexican } \\
\text { Spotted Owl }\end{array}$ & 93.8 & 0.0 & 6.1 \\
\hline Fort Polk & $\begin{array}{l}\text { Red-cockaded } \\
\text { Woodpecker, } \\
\text { Louisiana } \\
\text { Pinesnake }\end{array}$ & 93.7 & 0.3 & 6.1 \\
\hline $\begin{array}{l}\text { Fort Hunter } \\
\text { Liggett }\end{array}$ & $\begin{array}{l}\text { San Joaquin } \\
\text { Kit Fox }\end{array}$ & 93.2 & 1.2 & 5.6 \\
\hline $\begin{array}{l}\text { MTC-H Camp } \\
\text { Roberts }\end{array}$ & $\begin{array}{l}\text { San Joaquin } \\
\text { Kit Fox }\end{array}$ & 93.2 & 1.2 & 5.6 \\
\hline $\begin{array}{l}\text { Fort Hunter } \\
\text { Liggett }\end{array}$ & Purple Amole & 91.7 & 2.3 & 6.1 \\
\hline $\begin{array}{l}\text { MTC-H Camp } \\
\text { Roberts }\end{array}$ & Purple Amole & 91.7 & 2.3 & 6.1 \\
\hline Camp Shelby & $\begin{array}{l}\text { Red-cockaded } \\
\text { Woodpecker, } \\
\text { Gopher } \\
\text { Tortoise, Black } \\
\text { Pinesnake }\end{array}$ & 91.0 & 3.7 & 5.3 \\
\hline VTS Catoosa & $\begin{array}{l}\text { Large-Flowered } \\
\text { Skullcap }\end{array}$ & 90.7 & 2.7 & 6.6 \\
\hline $\begin{array}{l}\text { Dugway } \\
\text { Proving } \\
\text { Ground }\end{array}$ & Pygmy Rabbit & 90.5 & 0.2 & 9.3 \\
\hline
\end{tabular}




\begin{tabular}{|c|c|c|c|c|}
\hline Installation & Species & $\begin{array}{l}\text { Percent Public } \\
\text { Lands }\end{array}$ & $\begin{array}{l}\text { Percent Private } \\
\text { Conservation } \\
\text { Lands }\end{array}$ & $\begin{array}{l}\text { Percent Other } \\
\text { Private Lands }\end{array}$ \\
\hline VTS Catoosa & $\begin{array}{l}\text { Northern Long- } \\
\text { eared Bat }\end{array}$ & 89.6 & 3.5 & 6.9 \\
\hline Fort Polk & $\begin{array}{l}\text { Northern Long- } \\
\text { eared Bat }\end{array}$ & 88.9 & 1.0 & 10.1 \\
\hline $\begin{array}{l}\text { Fort Chaffee } \\
\text { Maneuver } \\
\text { Training Center }\end{array}$ & Geocarpon & 88.7 & 3.1 & 8.2 \\
\hline $\begin{array}{l}\text { Fort Hunter } \\
\text { Liggett }\end{array}$ & $\begin{array}{l}\text { California } \\
\text { Condor }\end{array}$ & 88.2 & 3.0 & 8.7 \\
\hline Camp Gruber & $\begin{array}{l}\text { Northern Long- } \\
\text { eared Bat }\end{array}$ & 88.1 & 0.7 & 11.3 \\
\hline Fort Carson & $\begin{array}{l}\text { Mexican } \\
\text { Spotted Owl }\end{array}$ & 87.7 & 1.9 & 10.4 \\
\hline $\begin{array}{l}\text { Fort Chaffee } \\
\text { Maneuver } \\
\text { Training Center }\end{array}$ & $\begin{array}{l}\text { American } \\
\text { Burying Beetle }\end{array}$ & 87.2 & 0.8 & 12.0 \\
\hline Fort Riley & $\begin{array}{l}\text { Northern Long- } \\
\text { eared Bat }\end{array}$ & 85.4 & 5.5 & 9.1 \\
\hline Fort Jackson & $\begin{array}{l}\text { Smooth } \\
\text { Coneflower }\end{array}$ & 83.5 & 2.8 & 13.7 \\
\hline Fort Gordon & Gray Bat & 82.4 & 4.6 & 13.0 \\
\hline $\begin{array}{l}\text { Fort Gordon, } \\
\text { Fort Jackson }\end{array}$ & $\begin{array}{l}\text { Red-cockaded } \\
\text { Woodpecker }\end{array}$ & 81.1 & 3.3 & 15.6 \\
\hline Fort Knox & Indiana Bat & 80.7 & 2.2 & 17.1 \\
\hline Fort Knox & $\begin{array}{l}\text { Northern Long- } \\
\text { eared Bat }\end{array}$ & 80.6 & 2.2 & 17.1 \\
\hline $\begin{array}{l}\text { Marseilles } \\
\text { Training Center }\end{array}$ & $\begin{array}{l}\text { Rusty Patched } \\
\text { Bumble Bee }\end{array}$ & 80.4 & 5.7 & 13.9 \\
\hline $\begin{array}{l}\text { White Sands } \\
\text { Missile Range }\end{array}$ & $\begin{array}{l}\text { Jaguar, } \\
\text { Todsen's } \\
\text { Pennyroyal }\end{array}$ & 78.8 & 0.0 & 21.2 \\
\hline Camp Dawson & $\begin{array}{l}\text { Northern Long- } \\
\text { eared Bat }\end{array}$ & 78.7 & 1.2 & 20.1 \\
\hline Fort Knox & Gray Bat & 77.7 & 1.0 & 21.3 \\
\hline
\end{tabular}




\begin{tabular}{|c|c|c|c|c|}
\hline Installation & Species & $\begin{array}{l}\text { Percent Public } \\
\text { Lands }\end{array}$ & $\begin{array}{l}\text { Percent Private } \\
\text { Conservation } \\
\text { Lands }\end{array}$ & $\begin{array}{l}\text { Percent Other } \\
\text { Private Lands }\end{array}$ \\
\hline Fort Hood & $\begin{array}{l}\text { Golden- } \\
\text { cheeked } \\
\text { Warbler }\end{array}$ & 77.3 & 9.6 & 13.1 \\
\hline $\begin{array}{l}\text { White Sands } \\
\text { Missile Range }\end{array}$ & $\begin{array}{l}\text { New Mexico } \\
\text { Jumping } \\
\text { Mouse }\end{array}$ & 77.3 & 0.0 & 22.7 \\
\hline Fort Campbell & $\begin{array}{l}\text { Northern Long- } \\
\text { eared Bat }\end{array}$ & 76.6 & 4.3 & 19.0 \\
\hline Camp Dawson & $\begin{array}{l}\text { Running } \\
\text { Buffalo Clover }\end{array}$ & 76.2 & 1.2 & 22.7 \\
\hline $\begin{array}{l}\text { Marseilles } \\
\text { Training Center }\end{array}$ & $\begin{array}{l}\text { Northern Long- } \\
\text { eared Bat }\end{array}$ & 73.8 & 3.5 & 22.7 \\
\hline $\begin{array}{l}\text { White Sands } \\
\text { Missile Range }\end{array}$ & $\begin{array}{l}\text { Southwestern } \\
\text { Willow } \\
\text { Flycatcher }\end{array}$ & 73.8 & 11.9 & 14.1 \\
\hline $\begin{array}{l}\text { Fort Gordon, } \\
\text { Fort Jackson }\end{array}$ & $\begin{array}{l}\text { Northern Long- } \\
\text { eared Bat }\end{array}$ & 73.0 & 10.0 & 17.0 \\
\hline $\begin{array}{l}\text { Camp } \\
\text { Atterbury }\end{array}$ & $\begin{array}{l}\text { Northern Long- } \\
\text { eared Bat }\end{array}$ & 72.9 & 2.4 & 24.7 \\
\hline $\begin{array}{l}\text { Camp } \\
\text { Atterbury }\end{array}$ & Indiana Bat & 72.8 & 2.3 & 24.9 \\
\hline Fort Bragg & $\begin{array}{l}\text { Red-cockaded } \\
\text { Woodpecker, } \\
\text { American } \\
\text { Chaffseed, } \\
\text { Michaux's } \\
\text { Sumac }\end{array}$ & 68.1 & 5.0 & 26.9 \\
\hline $\begin{array}{l}\text { MTC Camp } \\
\text { Blanding }\end{array}$ & $\begin{array}{l}\text { Chapman } \\
\text { Rhododendron }\end{array}$ & 67.4 & 0.2 & 30.1 \\
\hline $\begin{array}{l}\text { MTC Camp } \\
\text { Blanding }\end{array}$ & $\begin{array}{l}\text { Red-cockaded } \\
\text { Woodpecker, } \\
\text { Eastern Indigo } \\
\text { Snake }\end{array}$ & 67.1 & 2.3 & 30.7 \\
\hline $\begin{array}{l}\text { White Sands } \\
\text { Missile Range }\end{array}$ & $\begin{array}{l}\text { Western } \\
\text { Yellow-billed } \\
\text { Cuckoo }\end{array}$ & 66.4 & 0.0 & 33.6 \\
\hline
\end{tabular}




\begin{tabular}{|c|c|c|c|c|}
\hline Installation & Species & $\begin{array}{l}\text { Percent Public } \\
\text { Lands }\end{array}$ & $\begin{array}{l}\text { Percent Private } \\
\text { Conservation } \\
\text { Lands }\end{array}$ & $\begin{array}{l}\text { Percent Other } \\
\text { Private Lands }\end{array}$ \\
\hline $\begin{array}{l}\text { MTC-H Camp } \\
\text { Grayling }\end{array}$ & $\begin{array}{l}\text { Kirtland's } \\
\text { Warbler }\end{array}$ & 65.8 & 0.2 & 34.0 \\
\hline Fort McCoy & $\begin{array}{l}\text { Rusty Patched } \\
\text { Bumble Bee }\end{array}$ & 65.5 & 3.6 & 30.9 \\
\hline $\begin{array}{l}\text { Fort Leonard } \\
\text { Wood }\end{array}$ & $\begin{array}{l}\text { Northern Long- } \\
\text { eared Bat }\end{array}$ & 63.5 & 2.1 & 34.4 \\
\hline $\begin{array}{l}\text { Fort Leonard } \\
\text { Wood }\end{array}$ & Indiana Bat & 63.1 & 1.8 & 35.1 \\
\hline Fort Bragg & $\begin{array}{l}\text { Northern Long- } \\
\text { eared Bat }\end{array}$ & 63.0 & 9.3 & 27.7 \\
\hline Fort McCoy & $\begin{array}{l}\text { Karner Blue } \\
\text { Butterfly }\end{array}$ & 61.7 & 0.6 & 37.7 \\
\hline Camp Maxey & $\begin{array}{l}\text { American } \\
\text { Burying Beetle }\end{array}$ & 61.4 & 8.8 & 29.8 \\
\hline Fort Hood & $\begin{array}{l}\text { Black-capped } \\
\text { Vireo }\end{array}$ & 61.2 & 24.6 & 14.2 \\
\hline Fort Huachuca & $\begin{array}{l}\text { Huachuca } \\
\text { Water-Umbel }\end{array}$ & 59.7 & 8.6 & 30.5 \\
\hline Fort Stewart & $\begin{array}{l}\text { Smooth } \\
\text { Coneflower }\end{array}$ & 59.5 & 16.2 & 24.4 \\
\hline Fort McCoy & $\begin{array}{l}\text { Northern Long- } \\
\text { eared Bat }\end{array}$ & 59.4 & 4.2 & 36.5 \\
\hline $\begin{array}{l}\text { Fort Leonard } \\
\text { Wood }\end{array}$ & Gray Bat & 59.3 & 3.5 & 37.2 \\
\hline $\begin{array}{l}\text { MTC Camp } \\
\text { Blanding }\end{array}$ & $\begin{array}{l}\text { Florida Scrub } \\
\text { Jay }\end{array}$ & 58.7 & 4.1 & 37.1 \\
\hline Fort Huachuca & $\begin{array}{l}\text { Southwestern } \\
\text { Willow } \\
\text { Flycatcher }\end{array}$ & 57.7 & 13.3 & 28.2 \\
\hline $\begin{array}{l}\text { MTC-H Camp } \\
\text { Grayling }\end{array}$ & $\begin{array}{l}\text { Northern Long- } \\
\text { eared Bat }\end{array}$ & 57.6 & 0.3 & 42.1 \\
\hline Fort Stewart & Wood Stork & 56.7 & 5.2 & 38.1 \\
\hline
\end{tabular}




\begin{tabular}{|c|c|c|c|c|}
\hline Installation & Species & $\begin{array}{l}\text { Percent Public } \\
\text { Lands }\end{array}$ & $\begin{array}{l}\text { Percent Private } \\
\text { Conservation } \\
\text { Lands }\end{array}$ & $\begin{array}{l}\text { Percent Other } \\
\text { Private Lands }\end{array}$ \\
\hline Fort Stewart & $\begin{array}{l}\text { Red-cockaded } \\
\text { Woodpecker, } \\
\text { Eastern Indigo } \\
\text { Snake }\end{array}$ & 56.2 & 14.4 & 29.3 \\
\hline $\begin{array}{l}\text { MTC Camp } \\
\text { Blanding }\end{array}$ & Wood Stork & 56.0 & 3.9 & 40.1 \\
\hline $\begin{array}{l}\text { Ravenna } \\
\text { Training and } \\
\text { Log Site }\end{array}$ & $\begin{array}{l}\text { Northern Long- } \\
\text { eared Bat }\end{array}$ & 55.9 & 7.9 & 36.2 \\
\hline Fort Huachuca & $\begin{array}{l}\text { Northern } \\
\text { Aplomado } \\
\text { Falcon }\end{array}$ & 55.9 & 3.6 & 40.5 \\
\hline Fort Sill & $\begin{array}{l}\text { Black-capped } \\
\text { Vireo }\end{array}$ & 53.7 & 0.7 & 45.6 \\
\hline $\begin{array}{l}\text { MTA Camp } \\
\text { Edwards }\end{array}$ & $\begin{array}{l}\text { Northern Long- } \\
\text { eared Bat }\end{array}$ & 53.4 & 11.1 & 35.6 \\
\hline Fort Campbell & Gray Bat & 53.3 & 0.1 & 46.5 \\
\hline Fort Benning & $\begin{array}{l}\text { Northern Long- } \\
\text { eared Bat }\end{array}$ & 53.3 & 3.3 & 43.4 \\
\hline Fort Benning & $\begin{array}{l}\text { Red-cockaded } \\
\text { Woodpecker, } \\
\text { Relict Trillium }\end{array}$ & 53.1 & 2.8 & 44.1 \\
\hline Camp Ripley & $\begin{array}{l}\text { Northern Long- } \\
\text { eared Bat }\end{array}$ & 52.5 & 1.3 & 46.2 \\
\hline Fort Benning & Wood Stork & 51.3 & 2.0 & 46.7 \\
\hline Fort Dix & $\begin{array}{l}\text { Northern Long- } \\
\text { eared Bat }\end{array}$ & 51.1 & 6.5 & 42.4 \\
\hline Camp Ripley & Canada Lynx & 49.6 & 1.1 & 49.3 \\
\hline Fort Custer & $\begin{array}{l}\text { Northern Long- } \\
\text { eared Bat }\end{array}$ & 49.3 & 2.7 & 48.0 \\
\hline $\begin{array}{l}\text { Aberdeen } \\
\text { Proving } \\
\text { Ground }\end{array}$ & $\begin{array}{l}\text { Northern Long- } \\
\text { eared Bat }\end{array}$ & 48.7 & 12.6 & 38.7 \\
\hline $\begin{array}{l}\text { Fort } \\
\text { Indiantown } \\
\text { Gap }\end{array}$ & $\begin{array}{l}\text { Northern Long- } \\
\text { eared Bat }\end{array}$ & 48.7 & 12.6 & 38.7 \\
\hline
\end{tabular}




\begin{tabular}{|c|c|c|c|c|}
\hline Installation & Species & $\begin{array}{l}\text { Percent Public } \\
\text { Lands }\end{array}$ & $\begin{array}{l}\text { Percent Private } \\
\text { Conservation } \\
\text { Lands }\end{array}$ & $\begin{array}{l}\text { Percent Other } \\
\text { Private Lands }\end{array}$ \\
\hline $\begin{array}{l}\text { West Point } \\
\text { Military } \\
\text { Reservation }\end{array}$ & $\begin{array}{l}\text { Northern Long- } \\
\text { eared Bat }\end{array}$ & 48.5 & 5.3 & 46.2 \\
\hline $\begin{array}{l}\text { West Point } \\
\text { Military } \\
\text { Reservation }\end{array}$ & Indiana Bat & 48.4 & 5.2 & 46.5 \\
\hline Fort Huachuca & Gila Chub & 47.3 & 8.4 & 42.0 \\
\hline Fort Huachuca & $\begin{array}{l}\text { Chiricahua } \\
\text { Leopard Frog, } \\
\text { Gila } \\
\text { Topminnow, } \\
\text { Desert Pupfish }\end{array}$ & 47.3 & 8.4 & 42.0 \\
\hline $\begin{array}{l}\text { Macon } \\
\text { Training Site }\end{array}$ & Indiana Bat & 47.1 & 15.6 & 37.3 \\
\hline Fort Huachuca & $\begin{array}{l}\text { Canelo Hills } \\
\text { Ladies'-Tresses }\end{array}$ & 45.4 & 7.0 & 45.9 \\
\hline Fort Drum & Indiana Bat & 45.2 & 8.6 & 46.2 \\
\hline Fort Drum & $\begin{array}{l}\text { Northern Long- } \\
\text { eared Bat }\end{array}$ & 45.0 & 9.0 & 46.1 \\
\hline $\begin{array}{l}\text { Fort Hunter } \\
\text { Liggett }\end{array}$ & $\begin{array}{l}\text { Vernal Pool } \\
\text { Fairy Shrimp }\end{array}$ & 42.6 & 2.3 & 54.2 \\
\hline $\begin{array}{l}\text { MTC-H Camp } \\
\text { Roberts }\end{array}$ & $\begin{array}{l}\text { Vernal Pool } \\
\text { Fairy Shrimp }\end{array}$ & 42.6 & 2.3 & 54.2 \\
\hline $\begin{array}{l}\text { NG TS Ethan } \\
\text { Allen Range }\end{array}$ & $\begin{array}{l}\text { Northern Long- } \\
\text { eared Bat }\end{array}$ & 41.2 & 10.5 & 48.3 \\
\hline $\begin{array}{l}\text { Fort Hunter } \\
\text { Liggett }\end{array}$ & $\begin{array}{l}\text { Least Bell's } \\
\text { Vireo }\end{array}$ & 38.3 & 1.2 & 58.9 \\
\hline $\begin{array}{l}\text { MTC-H Camp } \\
\text { Grayling }\end{array}$ & Massasauga & 37.0 & 0.3 & 62.7 \\
\hline $\begin{array}{l}\text { MTC-H Camp } \\
\text { Grayling }\end{array}$ & $\begin{array}{l}\text { Houghton's } \\
\text { Goldenrod }\end{array}$ & 33.5 & 0.5 & 65.9 \\
\hline $\begin{array}{l}\text { Marseilles } \\
\text { Training Center }\end{array}$ & Massasauga & 32.5 & 2.6 & 62.3 \\
\hline $\begin{array}{l}\text { Fort Hunter } \\
\text { Liggett }\end{array}$ & $\begin{array}{l}\text { California Tiger } \\
\text { Salamander }\end{array}$ & 31.6 & 1.4 & 65.9 \\
\hline
\end{tabular}




\begin{tabular}{|c|c|c|c|c|}
\hline Installation & Species & $\begin{array}{l}\text { Percent Public } \\
\text { Lands }\end{array}$ & $\begin{array}{l}\text { Percent Private } \\
\text { Conservation } \\
\text { Lands }\end{array}$ & $\begin{array}{l}\text { Percent Other } \\
\text { Private Lands }\end{array}$ \\
\hline $\begin{array}{l}\text { Joint Base } \\
\text { Lewis-McChord }\end{array}$ & $\begin{array}{l}\text { Oregon } \\
\text { Spotted Frog }\end{array}$ & 29.4 & 2.5 & 65.3 \\
\hline $\begin{array}{l}\text { Joint Base } \\
\text { Lewis-McChord }\end{array}$ & $\begin{array}{l}\text { Chinook } \\
\text { Salmon }\end{array}$ & 29.1 & 0.5 & 68.1 \\
\hline Fort Huachuca & Spikedace & 28.2 & 0.4 & 67.2 \\
\hline $\begin{array}{l}\text { Camp San Luis } \\
\text { Obispo }\end{array}$ & $\begin{array}{l}\text { California Red- } \\
\text { legged Frog }\end{array}$ & 27.2 & 0.9 & 70.8 \\
\hline Fort Riley & Piping Plover & 27.1 & 0.4 & 72.6 \\
\hline $\begin{array}{l}\text { Joint Base } \\
\text { Lewis-McChord }\end{array}$ & Bull Trout & 26.9 & 0.4 & 67.0 \\
\hline Camp Grafton & $\begin{array}{l}\text { Northern Long- } \\
\text { eared Bat }\end{array}$ & 26.5 & 1.7 & 71.8 \\
\hline $\begin{array}{l}\text { Joint Base } \\
\text { Lewis-McChord }\end{array}$ & Water Howellia & 25.2 & 1.2 & 64.4 \\
\hline Fort Benning & $\begin{array}{l}\text { Choctaw Bean, } \\
\text { Fuzzy Pigtoe }\end{array}$ & 24.9 & 2.4 & 72.7 \\
\hline $\begin{array}{l}\text { Camp } \\
\text { Atterbury }\end{array}$ & Rayed Bean & 22.2 & 2.3 & 75.4 \\
\hline $\begin{array}{l}\text { Fort Hunter } \\
\text { Liggett }\end{array}$ & Arroyo Toad & 21.8 & 0.4 & 76.9 \\
\hline Fort McCoy & Massasauga & 21.7 & 3.0 & 75.3 \\
\hline $\begin{array}{l}\text { MTC-H Camp } \\
\text { Roberts }\end{array}$ & Steelhead & 21.6 & 0.5 & 77.1 \\
\hline Fort A. P. Hill & Swamp Pink & 17.2 & 3.1 & 78.6 \\
\hline $\begin{array}{l}\text { MTA Camp } \\
\text { Shelby }\end{array}$ & $\begin{array}{l}\text { Louisiana } \\
\text { Quillwort }\end{array}$ & 15.3 & 0.1 & 84.4 \\
\hline $\begin{array}{l}\text { MTA Camp } \\
\text { Shelby }\end{array}$ & Pearl Darter & 15.2 & 0.1 & 84.4 \\
\hline Fort Stewart & $\begin{array}{l}\text { Atlantic } \\
\text { Sturgeon, } \\
\text { Shortnose } \\
\text { Sturgeon }\end{array}$ & 13.7 & 2.4 & 83.9 \\
\hline Fort Bragg & $\begin{array}{l}\text { Rough-leaved } \\
\text { Loosestrife }\end{array}$ & 13.7 & 11.9 & 74.3 \\
\hline
\end{tabular}




\begin{tabular}{|c|c|c|c|c|}
\hline Installation & Species & $\begin{array}{l}\text { Percent Public } \\
\text { Lands }\end{array}$ & $\begin{array}{l}\text { Percent Private } \\
\text { Conservation } \\
\text { Lands }\end{array}$ & $\begin{array}{l}\text { Percent Other } \\
\text { Private Lands }\end{array}$ \\
\hline Parks RFTA & $\begin{array}{l}\text { California Red- } \\
\text { legged Frog }\end{array}$ & 10.6 & 7.3 & 80.6 \\
\hline Parks RFTA & $\begin{array}{l}\text { California Tiger } \\
\text { Salamander }\end{array}$ & 9.6 & 7.3 & 81.8 \\
\hline Fort Jackson & $\begin{array}{l}\text { Rough-leaved } \\
\text { Loosestrife }\end{array}$ & 8.8 & 3.1 & 88.0 \\
\hline Fort A. P. Hill & $\begin{array}{l}\text { Northern Long- } \\
\text { eared Bat }\end{array}$ & 7.8 & 3.4 & 88.8 \\
\hline Fort Eustis & $\begin{array}{l}\text { Northern Long- } \\
\text { eared Bat }\end{array}$ & 7.8 & 3.4 & 88.8 \\
\hline Fort Lee & $\begin{array}{l}\text { Northern Long- } \\
\text { eared Bat }\end{array}$ & 7.8 & 3.4 & 88.8 \\
\hline Fort Stewart & $\begin{array}{l}\text { Frosted } \\
\text { Flatwoods } \\
\text { Salamander }\end{array}$ & 7.0 & 2.3 & 90.6 \\
\hline $\begin{array}{l}\text { Fort Leonard } \\
\text { Wood }\end{array}$ & Spectaclecase & 6.0 & 0.3 & 93.7 \\
\hline $\begin{array}{l}\text { Fort Pickett } \\
\text { ARNG MTC }\end{array}$ & Yellow Lance & 5.9 & 3.4 & 90.1 \\
\hline $\begin{array}{l}\text { Fort Pickett } \\
\text { ARNG MTC }\end{array}$ & $\begin{array}{l}\text { Roanoke } \\
\text { Logperch }\end{array}$ & 5.9 & 3.4 & 90.1 \\
\hline Fort Bragg & $\begin{array}{l}\text { St. Francis } \\
\text { Satyr }\end{array}$ & 5.6 & 7.2 & 86.9 \\
\hline Fort A. P. Hill & $\begin{array}{l}\text { Small Whorled } \\
\text { Pogonia }\end{array}$ & 5.2 & 3.5 & 91.4 \\
\hline $\begin{array}{l}\text { Camp } \\
\text { Atterbury }\end{array}$ & $\begin{array}{l}\text { Snuffbox } \\
\text { Mussel }\end{array}$ & 4.6 & 0.6 & 94.8 \\
\hline Fort Huachuca & $\begin{array}{l}\text { Sonora Tiger } \\
\text { Salamander }\end{array}$ & 4.4 & 1.3 & 94.2 \\
\hline Fort Custer & Massasauga & 4.2 & 0.4 & 95.1 \\
\hline $\begin{array}{l}\text { Fort Pickett } \\
\text { ARNG MTC }\end{array}$ & $\begin{array}{l}\text { Michaux's } \\
\text { Sumac }\end{array}$ & 4.0 & 3.2 & 92.8 \\
\hline Fort Riley & Topeka Shiner & 0.0 & 0.0 & 100.0 \\
\hline
\end{tabular}




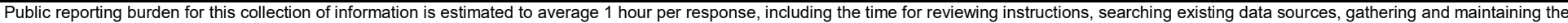

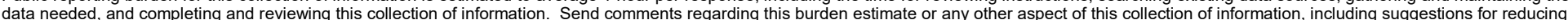

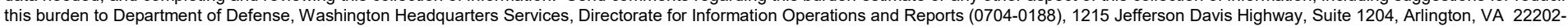

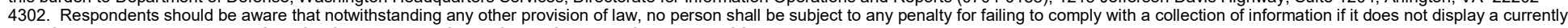
valid OMB control number. PLEASE DO NOT RETURN YOUR FORM TO THE ABOVE ADDRESS.
1. REPORT DATE (DD-MM-YYYY) March 2019 2. REPORT TYPE

\section{TITLE AND SUBTITLE}

A Regional Population Viability Approach for Threatened and Endangered Species

Management on Army Installations

\section{AUTHOR(S)}

William R. Fields, Wade A. Wall, Brett A. DeGregorio, and Matthew G. Hohmann

\section{PERFORMING ORGANIZATION NAME(S) AND ADDRESS(ES)}

U.S. Army Engineer Research and Development Center (ERDC)

Construction Engineering Research Laboratory (CERL)

PO Box 9005

Champaign, IL 61826-9005

\section{SPONSORING / MONITORING AGENCY NAME(S) AND ADDRESS(ES)}

Assistant Secretary of the Army for Acquisition, Logistics, and Technology

103 Army Pentagon

Washington, DC 20314-1000

\section{DISTRIBUTION / AVAILABILITY STATEMENT}

Approved for public release. Distribution is unlimited.

\section{DATES COVERED (From - To)}

5a. CONTRACT NUMBER

5b. GRANT NUMBER

5c. PROGRAM ELEMENT NUMBER

RDTE PE 896

5d. PROJECT NUMBER

P2 458334

5e. TASK NUMBER

\section{5f. WORK UNIT NUMBER}

BK8195

8. PERFORMING ORGANIZATION REPORT
NUMBER
ERDC/CERL TR-19-11

ERDC/CERL TR-19-11

10. SPONSOR/MONITOR'S ACRONYM(S)

$\operatorname{ASA}(\mathrm{ALT})$

11. SPONSOR/MONITOR'S REPORT NUMBER(S)

\section{SUPPLEMENTARY NOTES}

\section{ABSTRACT}

Regional partnering for threatened and endangered species (TES) management can be an effective strategy, allowing the Department of Defense to achieve conservation goals while minimizing potential conflict with its training and testing missions. However, the potential benefits of regional partnering are determined by where TES habitat occurs within a landscape, how populations interact with one another demographically, and the proportion of TES habitat managed by various agencies and potential partners. To assess the opportunities for and potential value of regional TES conservation partnering, we evaluated the relative conservation values of habitat networks for 84 TES known to occur on or near 54 Army and Army National Guard installations. The highest relative network conservation values were estimated for mammals and birds at Fort Huachuca. High relative network conservation values are associated with large amounts of public land. On average, $52.3 \%$ of identified habitat networks occurred on public lands compared to $3.8 \%$ on private conservation lands. Assessment of habitat networks provides an efficient framework for guiding regional partnering efforts, and multispecies regional conservation partnerships will be critical in addressing the combined threats of encroachment and climate change. Prioritization of regional conservation partnerships will maximize the benefits of limited conservation funding.

\section{SUBJECT TERMS}

Endangered species; Environmental protection; Military bases; Metapopulation; Military training camps; Environmental management; Regional planning; Conservation prioritization

\begin{tabular}{|c|c|c|}
\hline \multicolumn{3}{|c|}{ 16. SECURITY CLASSIFICATION OF: } \\
\hline $\begin{array}{l}\text { a. REPORT } \\
\text { Unclassified }\end{array}$ & $\begin{array}{l}\text { b. ABSTRACT } \\
\text { Unclassified }\end{array}$ & $\begin{array}{l}\text { c. THIS PAGE } \\
\text { Unclassified }\end{array}$ \\
\hline
\end{tabular}

\begin{tabular}{|c|c|c|}
\hline $\begin{array}{c}\text { 17. LIMITATION } \\
\text { OF ABSTRACT }\end{array}$ & $\begin{array}{c}\text { 18. NUMBER } \\
\text { OF PAGES }\end{array}$ & 19a. NAME OF RESPONSIBLE PERSON \\
\cline { 3 - 3 } UU & 56 & $\begin{array}{c}\text { 19b. TELEPHONE NUMBER (in- } \\
\text { clude area code) }\end{array}$ \\
\hline
\end{tabular}

